\title{
Las poesías de fray Luis de León, en francés
}

LUIS DE LEÓN: POÉSIES présentées, traduites du castillan et annotées par Patrick Négrier. Préface de Bernard Sesé. Sagesse Chrétienne. O.E.I.L. 12, rue du Dragon. 175006 Paris 1986, 20 x 13, 162 p.

\section{EL PRÓLOGO}

El prologuista, Bernard Sesé, es un buen conocedor de Fr. Luis. Lo había demostrado ya, en 1985, con la traducción al francés de las veintitrés poesías originales. En breves páginas, presenta a Fr. Luis como un humanista del Renacimiento, heredero de la tradición grecolatina y judeocristiana. Deseo de soledad y ansia de conocimiento es el doble anhelo que anima su poesía. Aspiración a la paz y al «concierto» (palabra maestra de sus escritos), pero sólo aspiración; en realidad, varón de dolores y combates. «Evoca con nostalgia el gozo místico, del que jamás tuvo experiencia personal». Con tan breves y acertadas palabras zanja la cuestión del misticismo de Fr. Luis, cuya existencia se han empeñado inútilmente en demostrar otros. Fr. Luis es un músico del verso, «con voluntad de estrofa»; un cuidadoso orfebre de la construcción poética, que se propuso, y lo consiguió, levantar el español a la altura del hebreo, griego y latín; un humanista cristiano. De ahí el influjo permanente que ha ejercido su poesía. El prologuista recuerda de manera expresa a Quevedo, Quintana, Menéndez Pelayo, Antonio Machado, Azorín, Unamuno, y a los poetas de la generación del 27, «segunda generación de poetas profesores» (la primera fue la de Fr. Luis, sucesora de la generación de poetas soldados, como Garcilaso...); entre ellos, a Gerardo Diego, García Lorca, Cernuda, Salinas, Aleixandre, Guillén. El fervor con que está escrito el prólogo no disminuye en nada su rigor científico, pese a su brevedad. Un solo lunar: en la p. 8 se llama a Fr. Luis «canónigo agustino»; expresión que se repite en la introducción hasta ocho veces; tanto más extraña 
cuanto que el prologuista y el traductor saben que fue «religioso de la Orden de Ermitaños de S. Agustín»; orden canónica, pero no de canónigos.

No es verdad que Cristóbal Cuevas no incluya a los tres franciscos (de la Torre, de Aldana, Medrano; a éste con reservas) en la Escuela poética de Salamanca. Los incluye y los tres están representados en la parte ontológica. Lo que Cuevas dice es que no son discípulos directos de Fr. Luis ${ }^{1}$.

\section{LA INTRODUCCIÓN}

Patrick Négrier es el autor de la introducción. Caracteriza bien la poesía de Fr. Luis: «fruto de elaborada meditación, obra de un espíritu sensible y culto, creyente e inteligente» (p. 30).

\section{Los temas}

Aunque nacidos todos de un mismo impulso interior, organiza los distintos poemas en cuatro apartados, considerando sucesivamente a Fr. Luis como; a) defensor de España; b) apóstol del eremitismo; c) teólogo del pecado y la salvación; d) cantor de la contemplación. Termina con un comentario de la oda X, una de las dedicadas a Felipe Ruiz.

Estudio atinado e inteligente, entusiasta y riguroso el que Négrier hace de Fr. Luis; pero, en ciencia, no hay nada absoluto. Cabe siempre la posibilidad de refutar o, al menos, de precisar lo que se dice. Y es precisamente «la contrastabilidad o refutabilidad» lo que distingue las teorías científicas, como bien ha señalado K.R. Popper.

Tan solo unas acotaciones sugeridas por la lectura de la introducción.

\section{a) Defensor de España}

Agrupa en este apartado las odas II, IV, VIII, XIII y XXI

Cierto que Fr. Luis canta las glorias de España, siendo estas exclusivamente heroicas, y celebra las virtudes de algunos nobles. Por contraposición, la morisma queda desprestigiada. La nobleza, en sus poesías, es siempre virtuosa y cristiana; y lo es por definición, como lo es en todos los escritores de su época, españoles o no. Aquellos hombres manejaban conceptos, esencias; no se ate-

1. Fr. Luis de León y la Escuela Salmantina. Taurus, Edic. Madrid 1986.

1a. Sigo la numeración de Négrier, que se atiene a la del P. Ángel Custodio Vega, Poesías de Fray Luis de León, edic. crítica. Editorial Saeta. Madrid 1955. En adelante, citaré las odas por su número y, a continuación, el de los versos: De los Nombres de Cristo por Nombres; la Exposición del Cantar de los Cantares por Cantar, con su capítulo y número; la Exposición del libro de $J o b$ por $J o b$, capítulo y número. En Nombres, la página remite a la edición del P. Félix García, Obras Completas Castellanas de Fray Luis de León, BAC. Madrid 1951, 2. ${ }^{\mathrm{a}}$ edic.). 
nían a lo particular y concreto. Las cosas eran como tenían que ser; como se creía que tenían que ser. Podía haber, y había, muchos nobles viciosos; pero eran la excepción que en nada desvirtuaba los principios establecidos. La nobleza seguía siendo, «de suyo», virtuosa. Formado en la tradición grecolatina y bíblica, viviendo en un momento triunfal de España, — «de la gloria estamos en la cumbre» (XXI,150) - era lógico que, al cantar a los héroes nacionales, adoptase el tono épico, que desrealiza a los individuos elevándolos a mitos.

Pero a todo esto hay que añadir que las poesías de tema nacional son primerizas. Que la atención a los individuos comenzaba por entonces, pero sólo comenzaba; tardó siglos en desarrollarse. Aún hay hoy quienes andan extraviados en los conceptos y esencias, tomándolos por la verdadera y única realidad, y no por lo que son. «La importancia del caso singular. Cuando estos fantasmas vivieron, solía decirse que la mirada a los árboles impedía ver el bosque. Y durante largas etapas llegó a olvidarse que también debemos mirar a un árbol tras otro para que nuestra visión del bosque (...como entonces se decía...) no se deshumanice. Finalmente, los hombres hubieron de aprenderlo para no sucumbir y ya no lo olvidaron» ${ }^{2}$. Romper con los arquetipos y crear personajes individuales fue el gran hallazgo de Cervantes. Con él comenzó la novela moderna. Lo que hay que indagar, por consiguiente, son los gérmenes de individualismo, y aun los posibles frutos que haya en Fr. Luis, que sí que los hay, al lado de las abstracciones y moldes genéricos, en los que se encajaba a todos por igual. Con los años, el tono de exaltación nacional perdió altisonancia y hasta desapareció. La Inquisición, de la que fue víctima, el problema de las castas y la honra (él tenía antecedentes judíos) y otros acontecimientos nacionales modificaron su visión de la realidad española.

Tampoco hay por qué extrañarse de que no comprendiera la cultura musulmana y de que, estudioso de la Biblia, de la tradición grecolatina y del humanismo italiano, no apreciara el Corán. Fr. Luis fue un humanista cristiano del Renacimiento. Nada menos, pero tampoco nada más. Cada estimación tiene su tiempo. Yo no sé de ningún hombre de aquella época que apreciara las creaciones de la civilización musulmana y se extasiara ante una mezquita árabe. Esto tardó aún siglos en llegar ${ }^{3}$. Por eso, creo que no se puede hablar de

2. Antonio Buero Vallejo, El tragaluz, parte primera, p. 70. Castalia Didáctica, Edit. Castalia, Madrid 1985.

3. Habla, sin embargo, con admiración, de los artesonados y «labores peregrinas» de los edificios de estilo árabe. Verdad es que era corriente, sobre todo entre el pueblo, atribuir las grandes obras a los moros. Obra de moros, se decía. Fr. Luis pondera el techo «fabricado / del sabio moro, en jaspes sustentado» (I, 9-10). «De labor peregrina, / una casa real vi, cual labrada / ninguna fue jamás por sabio moro» (XXIV, 16: imitación del Petrarca). «Aunque de marfil y oro / no está en mi casa el techo jaspeado / con la labor del moro» (traducción de la oda XVIII, 1.II, de Horacio, non ebur). «Significa la techumbre del edificio, hecha de artesones, obra morisca, compuesta de muchas piezas pequeñas» (Cantar 7,5). Fr. Luis vivió en Córdoba y, sobre todo, en Granada, residencia de sus padres. 
«espíritu de revancha (contra los moros), con que el autor expresa su patriotismo y nacionalismo avant la lettre» (p. 35), ni de «admiración exagerada por la nobleza y las virtudes de España» (p. 34).

Bien está la oda a Santiago en el momento en que se escribió y nada tiene de particular que un español escribiera, en el tono en que Fr. Luis lo hace, del Cid Campeador y, menos aún, de un héroe casi de sus días, Gonzalo Fernández de Córdoba, el Gran Capitán, y de sus gestas contra los franceses. Sus contemporáneos españoles se sentían también, y con razón, orgullosos de tanta hazaña. Que hoy las guerras nos provoquen náuseas es otra copla, pero esto no debe volvernos incapaces de entender el pasado. El mismo Négrier escribe en la p. 31: «Luis de León ha consagrado mucho a las alusiones históricas y a las descripciones épicas. Sin embargo, el lector espiritual tendrá autoridad suficiente en sí mismo para renunciar a una lectura literal y dar a las descripciones épicas un valor simbólico que las identifique con los combates espirituales, trascendiendo así su contenido».

Muy acertada la observación de que las alabanzas al «gran Portocarrero» son «medio sinceras, medio irónicas por su desmesura, y quizá oportunistas» (p. 34).

\section{b) Soledad y contemplación}

En el apartado «apóstol del eremitismo» se refiere a las odas I, VIII, XII, XIII, XV, XVII, XX y XXIII; y en el de «cantor de la contemplación», a las odas III, IV, VIII, IX, X, XVIII y XXII.

Fr. Luis amaba la soledad y el apartamiento, lo que Négrier llama «eremitismo», la paz y el reposo. También aquí se mezclaban en su espíritu las reminiscencias clásicas con las bíblicas y la posterior tradición cristiana, así como su propia experiencia de calumniado y perseguido. Al salir de la cárcel, se recrudeció esa aspiración. Léase su elogio de los ermitaños en Job 39, 8-11.

Mirar como ajeno lo que no está «dentro de uno mismo» (Nombres, 1.1, Pastor, 455), es decir, creer que cada uno se basta a sí mismo es, sin duda, estoico y Fr. Luis cita expresamente sobre el particular a Epicteto, pero es también cristiano. Entendámonos: cada uno se basta a sí mismo, se encierra en sí mismo y vive consigo, no para cultivar sus particularidades, que son ganga perecedera, sino para mejor encontrar su esencia humana, su naturaleza, aquello en lo que coincide con los demás hombres, y vivir de acuerdo con ello, sequere naturam; y, si es cristiano, para contemplar además su común condición, con los demás cristianos, de ser hijo de Dios en Jesucristo. Una larga tradición de escritores eclesiásticos, desde los Santos Padres, había bautizado y consagrado como cristiana tal doctrina, que quizá haya sido un quiste en el cristianismo, como otras doctrinas estoicas; la de la ley natural, por ejemplo. No entremos ahora en ello. Pedirse, pues, «a sí solo el gozo bueno», mirar 
«ajeno aquello que no está dentro en su seno» (XII, 22-25) no es estoico, sino cristiano; o mejor, estoicismo cristianizado. Tan verdad es esto que la oda, tras una alusión personal a la encina desmochada por el hierro, emblema de sus obras, termina celebrando a los mártires cristianos, fuertes y libres ante el tirano. No hay contradicción en ella ni es la segunda parte un añadido, como puede hacer creer una lectura apresurada. Del sabio estoico, «del moderado y constante», moderado en riquezas, honores, mando y placeres, a través de la experiencia personal se pasa al mártir cristiano, en quien se cumple real y verdaderamente aquel ideal, como expuso ya, en el siglo II, el apologista S. Justino ${ }^{4}$. No se trata, por consiguiente, de una «fórmula ambigua» (p. 37) y el mismo Négrier la entiende correctamente a continuación. En el interior de ese «sí solo» de Fr. Luis está Dios, y ahí, entrañado, está Jesucristo con su gracia, según expone en De los Nombres de Cristo, en especial al explicar el nombre de Pastor.

Fr. Luis no escribe para sí mismo ni por prurito estético, aunque cuide al máximo su estilo, sino para «servir a la Iglesia» (Nombres, 1.1, dedicatoria, 389), con lo cual se proclama fiel heredero de san Agustín. Servir a la Iglesia de su tiempo con obras «para el uso común de todos», en lengua vulgar y «nacidas de las Sagradas Letras o como allegadas y conformes a ellas» (Ib.), dada la necesidad en que se encontraban los fieles, a quienes se les había prohibido la lectura de la Biblia. En lengua vulgar, pero no vulgarmente (cf. Ib., 1,3 dedicatoria, 658). Sabía bien que las fuentes de la alegría no las puede buscar el hombre en sí mismo, sino en comunión con los demás, ayudando a construir la Iglesia. Como dice Négrier, a propósito de la oda XIV (contra un juez avaro), «Fr. Luis presenta, al menos implícitamente, la utilidad de la vida individual cuando está orientada hacia el bien común. Su participación provechosa en la Iglesia integra su ser, su energía y los frutos de su trabajo» (p. 41), renovando la herencia recibida y transmitiéndola a las generaciones siguientes. Como dice también Négrier: «Al escribir sus poesías, Luis de León hizo obra apostólica» (p. 32).

En la oda XIV, muestra la esterilidad de la vida empleada exclusivamente en la propia utilidad (avaricia y tiranía). Al fondo de las reminiscencias clásicas, bien perceptibles, está el recuerdo bíblico de la parábola del rico insensato, al que la muerte despoja de todos sus bienes (Lc 12, 15-21), y de otros textos similares en los que se censura el «amontonar» riquezas. «Y quedarás sumido / en males no finibles, y en olvido» (XIV, 29-30). Está claro que los «males no finibles» son la condenación eterna. En consecuencia, la conclusión es obvia, aunque Fr. Luis no la diga expresamente: «sed ricos para Dios»,

4. Cf. Theofried BaúmeIster, Mártires y perseguidos en el cristianismo primitivo, Concilium 183 (Marzo 1983), 312-320. 
«amontonad riquezas en el cielo», como dice el Evangelio. Al leer a Fr. Luis, nunca debemos quedarnos en los clásicos griegos y latinos. Éstos son sólo arroyos que van a engrosa el gran caudal bíblico, que es el que en realidad alimenta sus escritos. No lo olvidemos: sus libros son «nacidos de las Sagradas Letras o como allegados y conformes con ellas».

Si hablamos de eremitismo en Fr. Luis, hay que hacerlo con tiento. Aspiración profunda a la soledad, sí; ansia de apartamiento, de huir del «mundanal ruido» $(I, 2)$ y dedicarse a la contemplación; celebración de la vida retirada o «escondida senda» (I, 3-4), que sólo en Dios pone sus esperanzas. Pero este deseo sólo se vio realizado en alguna ocasiones. La soledad no es posible como forma absoluta de vida o, al menos, no le fue posible a él. Otras fuerzas le llevaban en sentido contrario. Por ello, anhela esos momentos de quedarse a solas en el campo o en el silencio de la noche, y desde esa soledad, «esclarecido de su primer origen» (III,10), como al escuchar la música de Salinas, gime y suspira por el cielo, su patria de origen y destino. En esta tensión dramática está el mejor Fr. Luis y no debemos prescindir de ninguno de los dos polos ${ }^{5}$. Cada frase es rama de un árbol frondoso y, sólo inserta en él, nos entrega su auténtico sentido.

Fr. Luis estaba dentro de una tradición secular, pagana y cristiana, según la cual el destino «natural» del hombre es la contemplación: para eso nace. Había quienes a ella consagraban su vida entera ${ }^{6}$. Pero había quienes, aun manteniendo como ideal la vida dedicada enteramente a la contemplación, porque otra cosa sería negar la propia esencia del hombre y violentar su inclinación natural, «toleraban» los negocios humanos y las actividades apostólicas, imposibles de soslayar mientras se está en este mundo. El hombre necesita de los demás y hay que predicar el Evangelio. Un hombre tan amante de la soledad como Fr. Luis fue quien escribió, sin embargo, estas frases: «De manera

5. Cf. Dámaso Alonso, Vida y poesía en Fray Luis de León, Obras Completas, t. II 789842. Edit. Gredos, Madrid 1973.

6. Solus cum solo fue el lema desde los primeros Padres del desierto: solo con Dios solo; a solas el monje con Dios, nadie más. "Con solo Dios se compasa / y a solas su vida pasa» (XXIII, 3-4). Todavía en el siglo XVII, las Constituciones de las agustinas recoletas, y podrían citarse cualesquiera otras de Órdenes contemplativas, mandan que, «además de las horas acostumbradas de oración», que les ocupaban casi toda la jornada, «vivan solas con Dios» el día anterior a los señalados para comulgar, privándose del recreo y hablando sólo por imperiosa necesidad (Constituciones, c. VI, n. ${ }^{\circ}$ 6. Cf. Carlos Alonso, Documentos inéditos sobre el convento de la Encarnación de Madrid de agustinas recoletas, Analecta Augustiniana, vol. XLIX (1986), 289). «Amen la soledad y sepan que la celda es el cielo del alma. No salgan de ella, a no ser por necesidad. Piensen que Dios queda en la celda y allí las espera. Convénzanse que Dios se goza con las almas en la soledad y, al volver a la celda, den gracias a Dios, que en ella mora, por verse de nuevo en ella» (Ib., c. VII, n. ${ }^{\circ}$ 7). Por lo visto, Dios no está más que en la celda, en la soledad, lejos de toda.criatura - ¿para qué las habrá creado entoces?-; y sólo retirándose a la soledad y entrando en soledad con él se le encuentra. 
que por ser Dios tan cabal y tan grande, es necesario que sea fecundo y que engendre, porque la soledad es cosa tristísima... Por donde, así como fue necesario que Dios tuviese Hijo, porque la soledad no es buena, así convino también que el Hijo no estuviese fuera del Padre, porque la división y apartamiento es negocio peligroso y ocasionado» (expuesto a peligros y quebrantos) (Nombres, 1.3, Hijo de Dios, 671). «El cristiano ha de responder a la necesidad de los prójimos», se lee en unos apuntes, posiblemente de Fr. Luis, que se encontraban en el mismo manuscrito - ¿desaparecido? - que el opúsculo sobre Los Nombres de Cristo ${ }^{7}$. Siendo esto así, les quedaba como única solución consagrar a la contemplación todo el tiempo que sus ocupaciones les dejasen libre y suspirar y aun gemir porque pasara cuanto antes «el papel de este mundo» (1Cor 7,31) para poder contemplar a Dios «cara a cara» (1Cor 13,12); «aguantar» la actividad y añorar el gozo contemplativo del sábado eterno, el ver «la verdad pura, sin velo» $(\mathrm{X}, 5)$. De éstos fue Fr. Luis, como antes lo había sido san Agustín.

Las palabras de Fr. Luis que acabo de citar van, sin embargo, en dirección muy distinta de la tradicional. La «soledad no es buena» y el «apartamiento es negocio peligroso y ocasionado», porque el hombre se forma y enriquece en el mundo. El hombre es relación, ésta es la consistencia propiamente humana, y sólo en ella se hace hombre cabal y «es fecundo y engendra». Me recuerdan estas reflexiones otras de san Agustín: «Raquel (la vida contemplativa) eligió tener hijos, antes que quedarse absolutamente sin descendencia» (C. Faust., 22,54), haciéndose activa, comunicando y enriqueciendo a los demás con lo aprehendido en la contemplación y enriqueciéndose ella misma. «La soledad es cosa tristísima». «Una persona sola no es persona», ha dicho Unamuno en nuestros días, y Antonio Machado: «un corazón solitario / no es un corazón». ¿Se percataría Fr. Luis de la contradicción entre estas expresiones que acabo de citar sobre la soledad y aquellas otras en consonancia con la tradición? ¿Sacaría, al menos mentalmente, las debidas conclusiones? No es fácil responder a estas preguntas. Un sistema de siglos, con aportaciones de culturas dispares, está necesariamente herido de contradicciones internas y, sin embargo, o no se perciben o, si se perciben, no son lo suficientemente poderosas como para anularlo. Se vive en la creencia fundamental y en ella se insertan mal que bien las nuevas ideas. Lo cierto es que, según una tradición de siglos, el ideal era la contemplativa María, no la afanada Marta. La contemplación se ama; la acción, por muy evangélica que sea, se tolera, por necesidad, cuando no hay otro remedio. Que ésta sea la verdad del hombre, incon-

7. Cf. P. Ángel Custodio VeGA, Los nueve Nombres de Cristo ¿son de fray Luis de León? Imprenta del Real Monasterio de El Escorial 1945. 
cusa y eterna, y la verdad evangélica es ya otro tema; pero lo ha sido durante siglos, y hay que tenerlo en cuenta, si queremos entender los textos del pasado y no poner en ellos lo que no hay, ciegos para lo que hay.

\section{c) Teólogo del pecado y la salvación}

Aquí se agrupan las odas VI, VII, VIII, IX, X, XIV, XV, XVI, XIX, XXV y XXIX.

Hijo de la Biblia, buen discípulo de san Pablo y san Agustín, Fr. Luis pone al descubierto el mecanismo del pecado, que lleva en sí gérmenes de destrucción; denuncia la vanidad de los deseos mundanos y de las esperanzas terrenas; en especial, el poder terrible y enajenador de la fama. El moralista que hay en él asoma con frecuencia en sus poesías. Pero el pecado es sólo el aspecto negativo de la condición humana. Formando con él un solo y único tejido está la virtud y está la gracia. Y una y otra se celebran también con insistencia, así como el paso de aquel a estas mediante la conversión. «Parece que el pecado, a este respecto, juega el papel de trampolín hacia la salvación, escribe Négrier. Como un reactivo químico, el pecado es paradójicamente motor de santificación, como si el horror del mal y de la fealdad, llegado a su plenitud, pudiera abolir en él su reino» (p. 42). La gracia, de la que el hombre está necesitado, vence al pecado y el bien termina por imponerse al mal. Ninguna oda ilustra mejor este triple movimiento-pecado, conversión, estado de graciaque la oda VI (A la Magdalena), a la que ha dedicado recientemente un erudito y penetrante estudio Margherita Morreale ${ }^{8}$.

\section{d) Jesucristo, la Virgen y los santos}

No comparto, en cambio, esta afirmación de Négrier: «es absolutamente extraño que este cristiano católico tenga una predilección tan destacada por los santos, y tan poco afirmada por la figura de Cristo, al menos en las poesías: le dedica el poema 'A la Ascensión', un pasaje en la oda 'A todos los santos' y una alusión en el poema 'A la Magdalena'. Pero dedica un poema entero a la Virgen, sin contar las invocaciones diseminadas a lo largo de su obra» (p. 43).

Ni las menciones de los santos son tantas ni las de Jesucristo son tan pocas. ¿Qué tiene de extraño que un humanista cristiano, asiduo lector de Horacio, quisiera darle una réplica cristiana al Carmen saeculare horaciano en la Fiesta de todos los Santos; en que «el cielo hace alarde de su caballería» (XX, 8-9)? El curso de la oda sigue fielmente el movimiento horaciano. Los dioses

8. Cf. La oda VI de Fr. Luis de León: De la Magdalena. Entre poesía humanista y tradición medieval, RFE, t. LXV, julio-diciembre 1985 , cuadernos $3 .^{\circ}-4 .^{\circ}, 181-271$. 
paganos son sustituidos por Jesucristo, la Virgen y los ángeles; san Pedro y san Pablo ocupan el lugar de los Dioscuros, Cástor y Pólux; y los héroes romanos son desplazados por los santos, héroes y «caballeros de Dios», según una imagen usual en la época («caballeros andantes», claro). Al final de la oda, Fr. Luis prorrumpe en una oración personalísima por él y por la Iglesia, en la que pide a Dios Padre la reimplantación del cristianismo primitivo, «aquello antiguo, santo y llano» $(\mathrm{XX}, 85)$. Devoto de los santos, pero puestos en su sitio; como ramas de un árbol gigantesco que nos cobija a todos. Nada hay en la oda que disuene de las creencias de un cristiano católico. Como nada tiene de sorprendente, según queda dicho, que un español del siglo XVI celebrara a Santiago, patrón de España y atracción de peregrinos («al fin te adora el franco»: XXI, 166-167), con el entusiasmo con que Fr. Luis lo hizo. Puestos a ser hipercríticos, habría que preguntarse más bien por la ausencia de Santiago en la oda «A todos los santos»; pero no lo seamos. Ni es raro que, exhortando a una pecadora a la conversión, le propusiera como ejemplo a la Magdalena. Bastaría el buen sentido evangélico, y Fr. Luis lo poseía, para traérselo a la memoria. Pero hay que contar además con la devoción que entonces prosperaba a dicha santa, como atestiguan documentalmente las distintas artes y tratados doctrinales; devoción propagada en Occidente por las Órdenes Mendicantes, sobre todo; una de las cuales era la Orden de Ermitaños de san Agustín, a la que Fr. Luis pertenecía. Se puede apreciar, precisamente, su contención y medida, rasgo del auténtico clasicismo, comparando su expresión con la abundosa y pintoresca de su hermano de hábito Malón de Chaide, en el tratado que este escribió sobre «La conversión de la Magdalena».

Transmigremos por un momento a aquel tiempo en que el ritmo de la vida estaba marcado por las fiestas religiosas; en que los santos presidían el trabajo y ayudaban eficazmente en él; y cada gremio, profesión y clase social tenía asignados sus patronos, y todos llenaban con su presencia la liturgia de la Misa y de las Horas. Situados en esa perspectiva y tratándose de un religioso, ¿no habrá que destacar más bien su moderación y el haber sabido colocarlos en su lugar preciso, «conforme a lo que suelen hacer los que saben de pintura, y muestran algunas imágenes de excelente labor a los que no entienden tanto del arte, que le señalan los lejos y lo que está pintado como cercano, y les declaran las luces y las sombras y la fuerza del escorzadon? (La Perfecta Casada, Introducción, Obras Completas Castellanas, 236. edic. cit.).

Pues vengamos a las poesías dedicadas a la Virgen: una sólo, la XXII, y una estrofa en la oda «A todos los Santos». Cierto que, en la Oda «A Nuestra Señora», Fr. Luis, acosado por la persecución, respira honda, afectuosa y sincera piedad a Nuestra Señora, a cuyo amparo maternal se acoge con acentos que recuerdan sus traducciones de los Salmos; en especial, del Salmo XXIV, 


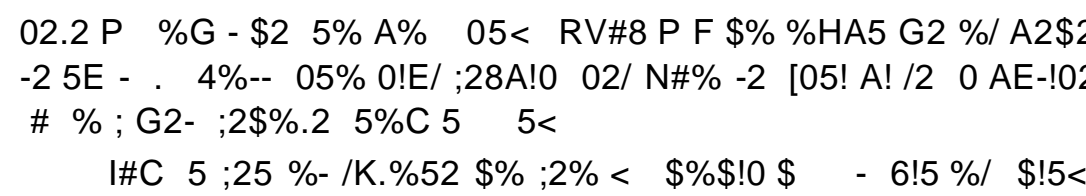

$\begin{array}{rrr}N n q u n u & d q u l, \\ \mathrm{~L} & \mathrm{o} & \mathrm{y}\end{array}$

. N

s.

á $\quad b \quad a$

; d

d

vi ú

$\mathrm{S}$

Fr. of $b$

$\mathrm{p}$

F

g M i

B $\quad$ b

n

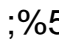

Lib de $v$ d ero

$C$ ist : $\mathrm{e}^{\text {ú }}$

ie

d (XXII 92-93

$41810 \mathrm{~S}$

rí

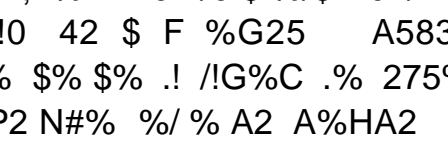

$D$ lo $N \quad b \quad s$

$m i$

$$
?
$$$$
\text { XVII }{ }^{11} . \mathrm{N}
$$

«fino» $m$

i $c$

1

. C

12. E E
b d e a

S )

M cí

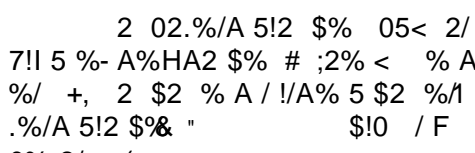

$\begin{array}{llll} & \mathrm{d} & & \\ & & \mathrm{h} & \\ & & u & d \\ & & ; & \mathrm{x}\end{array}$

n

b c n

a

. $\mathrm{S} m$ i cf. U. DoM G EZ D L V L,

log ca $C u \quad D s$ CLIV (14)

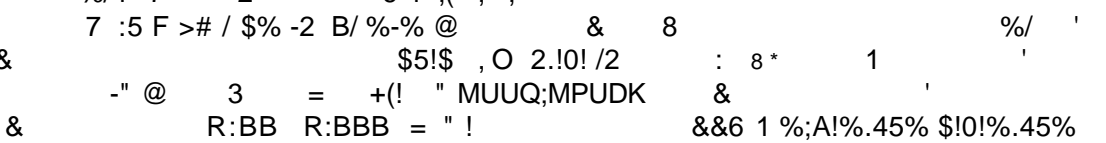

v $1.7 \quad 39$

2. $\begin{array}{ccccccc} & 39 & & & & & \\ \mathrm{~L} & \mathrm{p} & \mathrm{v} & \mathrm{j} & \mathrm{J}\end{array}$

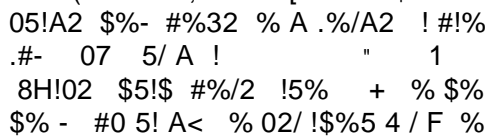

n
L a
f

ab $y$

b a

o e $\quad{ }_{M}^{\mathrm{g}} . \mathrm{P}$
c ins o. 582 590. F E, Mar y m. $t$ pe -


misma matriz socio-cultural, tejidas todas ellas de una misma sustancia histórica. Pero ésta, como vida que es, cambia y se modifica sin cesar, mientras que aquellas se petrifican; porque fuera del momento histórico que las originó no tienen sentido. Pueden, sí, subsistir con apariencias de vida en gentes aferradas a los viejos usos; pero son sólo apariencias. Cuando se las somete a riguroso análisis, no resisten el cotejo con la vida y se desmoronan. No hay que lamentarse de ello, sino de haberse situado fuera de la realidad, en espléndido aislamiento, tomando el rábano por las hojas.

En cuanto a Jesucristo, no son tan escasas las veces que aparece en las poesías de Fr. Luis. De él habla no sólo en la oda «A todos los Santos» (dos estrofas) y en el poema «A la Magdalena», en el que, por cierto, no hay sólo una alusión, sino que las diez estrofas de la segunda parte reviven la escena evangélica y en ellas Cristo es el personaje principal. También aparece repetidas veces, y no podía ser de otro modo, en la oda «A nuestra Señora». Además, seis estrofas de la oda «A Santiago» celebran la fe del apóstol y su martirio. En ellas es también Jesucristo el protagonista. Es él, Cristo, el «amante» que tira del discípulo y lo atrae hacia sí (XXI, 33), como atrajo también a la Magdalena, «derrocada / a los divinos pies que la traían» (VI, 56-57). Santiago, incapaz de «sufrir larga ausencia» (XXI, 26), es el primero en seguirle «por los pasos que había ido» (XXI, 35). (Amante y ausencia aparecen tam,bién en la redacción primitiva de la oda «A la Ascensión». ¿Qué «te detiene y

para que no desdijera de «la blanca pureza de la Virgen María, de quien su hijo había de ser perpetuo esclavo» (Claudio Burón, Vida del Bto. Alonso de Orozco, por un agustino anónimo del siglo XVII, c. I, Archivo Agustiniano, vol. LXX (enero-diciembre 1986), núm. 188, 333). «Tan enamorado de agradecido estaba de la Virgen Stma. el siervo de Dios, que tenía grabada en su corazón su hermosísima imagen... Dulcemente enamorado de su protectora..., procurando desempeñarse como agradecido galán. Tan enamorado de agradecido estaba su pecho... Su pecho se abrasaba con la encendida y fogosa llama de amor... Pasaban tan adelante los efectos de esta amorosa llama, que en todo el día, sin embarazarle ocupación alguna, era María su continua aclamación. A cultivar las flores de un jardín iba con el cuidado de conservar las más bellas para presentar a María Stma. ramilletes... Se regalaba con elevado espíritu repitiendo los himnos... No se contentaba con rezar los himnos, sin que la armonía de la voz se emplease, como fino enamorado, en cantarlos a su Madre y Señora. (...Retrasaba el sueño rezando a la Virgen y en sueños hablaba con ella...). Efecto natural de la fantasía que, acostumbrada a tal empleo, no olvida entre suefios lo que continuó despiertos los sentidos. Tan connaturalizado estaba por la gracia de Dios este amor de su Stma. Madre en el pecho de su siervo, que como quien se dolía de lo que le había faltado de continua fineza, la solía continuar en los suenos... Con los que sabrosamente con su nombre en el alma y en los labios se dejaba dormir con sabroso gozo de enamorado de la santa belleza de la Madre de Dios... Su siervo se abrasaba de amores» (Id., Ib., c. XIX, 393-394). Los subrayados son míos; «Tenía grabada en su corazón su hermosísima imagen» (de María). Como «fino» amador. Entre los amantes, había quienes no se contentaban con llevar dibujada interiormente, en su corazón, la imagen de la amada - «los ojos deseados / que tengo en mis entrañas dibujados» (dijo a lo divino S. Juan de la Cruz) -, sino que se tatuaban el pecho con ella o llevaban cosido en su traje su retrato. Así también los devotos. De Enrique Susón se cuenta que llevaba tatuado el nombre de Jesús en la parte del corazón y lo comparaba con el retrato de la amada. 
encadena / a no seguir tu amante?... ¿Podrá el terreno amor más que la ausencia / de tu querer y vida?» (XIX, 31-32 y 37-38). Y no sólo le consagra la oda «A la Ascensión», que hubiera sido suficiente para dejar constancia del puesto central que Jesucristo ocupaba en su vida, sino también la XVIII, «Morada del cielo», en la que Cristo es «el Buen Pastor», «pastor y pasto él solo y suerte buena» (XVIII, 20). Comentario de esta oda es el nombre de Pastor, y su lectura basta y sobra para percatarse de la predilección de Fr. Luis por Jesucristo.

A todo esto hay que añadir, limitándonos estrictamente a sus poesías, sus traducciones poéticas sagradas; en especial, las de los Salmos. Sabido es que de los Salmos y, en general, del Antiguo Testamento se hacía una lectura fundamentalmente cristológica, también eclesial y mariana. "Según las Escrituras», se repite a lo largo del Nuevo Testamento; y en los Evangelios se presenta a Jesús interpretando el milagro de Jonás como signo de la Resurrección e identificándose a sí mismo con el Siervo de Yahvé. Siendo Jesucristo la plenitud de los tiempos, hacia él tenía que encaminarse toda la historia precedente, y por él clamaban cielos y tierra. «Cristo es el fruto para cuya producción se ordenó y fabricó todo el mundo... Los cielos y la naturaleza toda vivía y tenía ser principalmente para este parto» (Nombres, 1.1, Pimpollo, 416). Todo, en el cosmos y en la historia, era anuncio y premonición, símbolo de lo que iba a vefiir, y hacia él se encaminaba, porque fuera de él no tenía sentido. Buena prueba de esto son los comentarios cristológicos que, siguiendo a san Agustín, hace Fray Luis de los Salmos que cita en De los Nombres de Cristo y la interpretación, también cristológica, que da de los textos del Antiguo Testamento que cita al comenzar cada nombre. Nuestra concepción de la historia es, sin duda, otra y otra nuestra lectura del Antiguo Testamento. Razón de más para ser cautos, al leer los textos del pasado; a los que hay que dejarles hablar y oír su voz, no la nuestra, y revolverles los suelos y zahondar en el subsuelo y explorar sus sótanos y galerías hasta palparles los entresijos y ver lo que hay en ellos. Y mientras esto no se haga, en rigor no se han leído.

Hay que decir, sin embargo, que, si en la p. 43 Négrier se extraña de que la figura de Cristo esté tan poco resaltada en las poesías de Fr. Luis, en la p. 31 escribe: «Obra de un cristiano, las Poesías aluden constantemente a episodios de la vida de Cristo que el poeta no elude explícitamente, suponiendo que el lector al que se dirige está necesariamente informado de cultura bíblica».

Acierta plenamente Négrier, cuando rechaza los oscuros propósitos judaizantes que algunos críticos han querido descubrir en Fr. Luis. Es verdad que sus libros son, en su mayoría, comentarios del Antiguo Testamento; pero ya hemos visto desde qué perspectiva lo lee y cuáles son sus propósitos. «Su sentimiento convencido de la supremacía de la graciă, dada por el espíritu Santo, sin la cual nada es posible, le hace definitivamente próximo del espíritu del Nuevo Testamento» (p. 43). 


\section{El simbolismo}

En el poema X, «el autor manifiesta una inteligencia luminosa y penetrante de los misterios cosmológicos. En ella, las descripciones de los fenómenos físicos no son enteramente descripciones formales de la naturaleza; sugieren analogías profundas con la modalidad y las etapas del devenir espiritual», dice Négrier (pp. 31-32). «Este poema plantea al historiador de las ideas el siguiente enigma: ¿cómo un agustino del Renacimiento español pudo, en un escrito, relacionar figuras y revelar su conocimiento de un lenguaje que no se enseñaba en las facultades de Teología?» (p. 48). Su simbolismo, según Négrier, no debe confundirse con el de los que buscan a toda costa un sentido espiritual en los fenómenos de la naturaleza, como hizo el pagano Lucrecio; ni con el simbolismo abusivo de ciertos autores antiguos, como Orígenes; ni con las improvisaciones simbolistas de los poetas de fines del siglo XIX. «En el poema de Fr. Luis, estamos en presencia de un simbolismo sometido a leyes rigurosas, cuyo carácter tradicional se manifiesta en tres rasgos esenciales» (p. 49). Todos los símbolos son cosmológicos, salvo el «nivel y plomo» del v. 13; remiten a realidades espirituales, porque la naturaleza es un macrocosmos o templo en el que se revela Dios; no se ven estática, sino dinámicamente, en sus relaciones «vivientes» (ciclos cósmicos). «Nuestra pregunta queda sin respuesta: ¿Cómo un agustino del siglo XVI pudo recibir y transmitir discretamente las figuras de un lenguaje que no se enseñaba sino por tradición iniciática? Sólo un historiador de las religiones podría contestarla» (p. 53).

Esta cuestión del simbolismo merece un comentario, siquiera raudo.

\section{a) El mundo visible, símbolo del mundo invisible}

Que la naturaleza es huella del Creador y que el mundo invisible se hace presente en el visible, aunque sólo en vislumbres que necesitan ser descifrados, lo afirman todas las tradiciones religiosas, también la cristiana. De los mitos la recogió Platón y con la autoridad de san Agustín quedó asegurada su transmisión en Occidente ${ }^{13}$. Entre el macrocosmos del universo y el microcosmos

13. Una exposición sucinta y clara del universo como signo de Dios en S. Agustín puede verse en Victorino CAPÁNAGA, Introducción general a las Obras de san Agustín, t. I, 46-63. BAC, Madrid 1979, 5. ${ }^{a}$ edic. El texto que más influyó, en este sentido, en los espirituales fue el libro X de las Confesiones y el apócrifo Meditaciones, Soliloquios y Manual, atribuido a S. Agustín y muy leído durante la Edad Media y el siglo XVI (Cf. Marcel BATAILloN, Sobre la génesis poética del Cántico espiritual de San Juan de la Cruz, en Varia lección de clásicos españoles, 167-182. Edit. Gredos, Madrid 1964). Para S. Agustín el mundo es un poema, se dice. En realidad, el mundo es para él «carmen universitatis» (De musica, VI, XI, 29), que no debe traducirse por "poema», sino por "canción», como ya señaló Ernst RoBERT CURTIUS, (Cf. Literatura europea y Edad Media latina, II, 759. FCE, México-Madrid-Buenos Aires 1976). «El orden de los siglos es como una hermosísima canción embellecida de contrastes» (De civ. Dei, XI, 18), «el gran cántico de un cantor inefable» $(E p ., 138,5)$. 
del hombre hay secretas y muy sutiles relaciones de armonía, explicándose mutuamente uno por otro ${ }^{14}$.

Cristo es fruto del mundo, nos ha dicho Fr. Luis «Y como de ser Cristo llamado fruto por excelencia, entendemos que todo lo criado se ordenó para Él, así también de esto mismo ordenado, podemos, rastreando, entender el valor inestimable que hay en el Fruto para quien tan grandes cosas se ordenan. $\mathrm{Y}$ de la grandeza, hermosura y cualidad de los medios, argüimos la excelencia sin medida del fin» (Nombres, 1.1, Pimpollo, 415). El mundo visible del hombre primero y sus descendientes y el invisible del hombre nuevo, nacido en Cristo, o Iglesia se corresponden. Si en aquél hizo Dios «cielos y tierra y los demás elementos..., hizo en la Iglesia sus cielos y tierra, y vistió a la tierra con frutos y a los cielos con estrellas de luz. Y lo que hizo en aquesto visible, eso mismo ha obrado en lo nuevo invisible, procediendo en ambos por unas mismas pisadas, como lo dibujó, cantando divinamente, David en sus salmos [se refiere, en concreto, al salmo 103, que comenta]. Adonde por unas mismas palabras, y como con una voz, cuenta alabando a Dios, la creación y gobernación de aquestos dos mundos; y diciendo lo que se ve, significa lo que se esconde, como san Agustín lo descubre, lleno de ingenio y de espíritu» (Nombres, 1. 1, Padre del siglo futuro, 504).

Aquí queda bien al descubierto una de las claves del pensamiento de Fr. Luis, de su técnica exegética y de su creación poética. Detrás del significado inmediato hay otro misterioso y secreto del que aquél es metáfora, como lo es el mundo visible de la realidad auténtica y verdadera del invisible. El pecado ha dejado debilitado al hombre, incapaz de aprehender directamente lo espiritual y el mundo real del más allá. Necesita el tacatá de las imágenes, como niño que comienza a andar. «Esta manera de hablar, Juliano, adonde con semejanzas y figuras de cosas que conocemos y vemos y amamos, nos da Dios noti-

En su tenor literal, estos textos agustinianos se refieren al sucederse de las generaciones, es decir, al mundo histórico; pero se aplican también, y no sin razón, al mundo físico. «El cosmos viene a ser un himno a la concordia que el Sumo Bien despliega numerosamente, es decir, con sonoridad plena e indecible. De aquí que el universo sea como un poema, ya que música y poesía son hermanas» (Luis Morales Oliver: La música de Salinas en la poesía de Fray Luis de León, en Cuadernos para investigación de la literatura hispánica, núms. 2-3, Fundación Univ. Española (1980), 419). El mismo san Agustín usa la imagen del poema para describir el universo y sus mudanzas: «ni por los sentidos del cuerpo ni por la reflexión del alma puedes percibir las cosas mudables, si no subsisten en alguna forma numérica. No dudes, pues, que para que no perezcan y formen el poema de los tiempos (quasi quosdam versus temporum peragant) con sus movimientos concordes y su diferenciada variedad de formas es necesario que exista una forma eterna e inmutable que las forme» (De lib. arb., II, 16, 44).

Del cosmos, «unidad primaria y radical de todas las realidades intramundanas», ha escrito Zubiri: «no es sino una especie de melodía dinámica que se va haciendo en sus notas» (Sobre el hombre, 466. Alianza Editorial, Madrid 1986).

14. Cf. Francisco Rico, El pequeño mundo del hombre. Edit. Castalia, Madrid 1970. 
cia de sus bienes y nos lo promete, para la cualidad y gusto de nuestro ingenio y condición, es muy útil y muy conveniente. Lo uno, porque todo nuestro conocimiento así como comienza de los sentidos, así no conoce bien lo espiritual, si no es por semejanza de lo sensible que conoce primero. Lo otro, porque la semejanza que hay de lo uno a lo otro, advertida y conocida, aviva el gusto de nuestro entendimiento naturalmente, que es inclinado a cotejar unas cosas con otras discurriendo por ellas; y así, cuando descubre alguna gran consonancia de propiedades entre cosas que son en naturaleza diversas, alégrase mucho, y como saboréase en ello, e imprímele con más firmeza en las mientes. Y lo tercero, porque de las cosas que sentimos, sabemos por experiencia lo gustoso y lo agradable que tienen; más de las cosas del cielo no sabemos cuál sea ni cuánto su sabor y dulzura» (Nombres, 1.2, Brazo de Dios, 529).

Detrás, por consiguiente, del significado evidente y próximo que nos entrega la lectura de sus poesías hay otro oculto y espiritual, que para él era el más importante. Y hasta ese hondón hay que llegar, porque es ahí donde está el manantial vivo y perenne de sus versos. Hay que descifrar el primero; descubrir, mediante las técnicas de investigación lingüística y literaria, las infinitas riquezas que entraña, pues estamos ante un poeta que no dejó nada al azar; pero no podemos olvidar que toda esa prodigiosa tracería no es sino símbolo de un denso y misterioso mundo interior. Para entender sus poemas tenemos que seguir el mismo proceso que siguó él en sus comentarios bíblicos: explicar, en primer lugar, las «palabras desnudas», como si nada más hubiera tras ellas, y pasar luego a los «misterios de gran secreto y de gran peso» que en ellas están aludidos (Cantar, prólogo, 63). Si el primero es «trabajo de grandes dificultades» (Ib.), el segundo es encontrar, cuanto más se anda, más camino que andar y descubrir «nuevos mares cuanto más navego» (Nombres, 1.1, Faces de Dios, 432).

En la oda X, por ejemplo, una tormenta primaveral arrasa los campos de Castilla. Haríamos mal, si empezáramos con piadosas consideraciones sobre las tormentas del espíritu. Ahí se habla, no hay duda, de una tormenta exterior; pero esa tormenta ha adquirido nueva realidad en unos versos que la configuran de manera ejemplar, al recrearla literariamente. Lo primero que hay que hacer es descifrar «a la letra» los significados; descubrir, mediante el análisis lingüístico y literario, en qué reside la fuerza de esos versos sobrecogedores, que se nos agarran a la garganta y nos encogen el alma; estudiar sus fuentes y los desvíos, si los hay, respecto a ellas; desvelar la visión de los fenómemos atmosféricos que subyace en esas estrofas; situar todo esto en su época y en la tradición anterior; entrar en la perspectiva del autor y desde ella leer lo que él ha escrito; desmontar, poniéndola al descubierto, la armazón de reglas y mecanismos generadores del sentido o, lo que es lo mismo, aplicar al texto el 
análisis semiótico. Todo, como si el único referente de esas estrofas fuera única y exclusivamente una tormenta de la naturaleza.

Pero sabemos que no es así; que la tormenta exterior es símbolo de estados espirituales íntimos o de conflictos sociales en que combaten fuerzas contrarias, «el cierzo y el ábrego» de la tempestad marina de la oda primera (6170); que todos estos significados envían a otro mundo, a experiencias más complejas y enmarañadas, a las que el rodeo por los elementos sensibles de la naturaleza ilumina y da fuerza y brío potenciados. Para entender y analizar lo cual es necesario proveerse del utillaje adecuado, que no es otro que la doctrina teológica y espiritual de Fr. Luis, así como sus conocimientos bíblicos y de la tradición eclesiástica. Él mismo, en los capítulos 37 y 38 de $J o b$, nos aclara este significado secreto de la tormenta, el cierzo y el ábrego. Así como por otros pasajes de sus obras nos enteramos de qué mundos interiores habla cuando dice monte, fuente, río, valle, prado... y tantas otras palabras usadas en sus versos. Tendremos que empezar a entender a Fr. Luis por Fr. Luis mismo, es decir, anotar sus poesías con pasajes de sus otras obras y no sólo con textos de Horacio y Virgilio ${ }^{15}$.

Se trata de símbolos, no de alegorías; al menos, de ordinario. Por eso, es inútil empeñarse en encontrar, al pormenor, equivalencias de todos y cada uno de los rasgos de la realidad externa en la realidad secreta. Por el contrario, ésta puede proyectarse sobre aquélla y dotarla de sus propios caracteres. Es inútil buscar en La Flecha el «monte» de la oda, porque no está en ella; como lo es interpretar, palabra por palabra, la realidad en ella aludida. Que en esa oda Fr. Luis habla de La Flecha para mí no tiene duda. Pero La Flecha, además de ser una finca concreta, por su soledad y apartamiento, por su huerto primaveral y por la fuente que se apresura es símbolo de una realidad espiritual. Aquélla es la apoyatura de que se vale para elevarse al mundo interior. El huerto exterior que contempla es, a sus ojos, imagen de su alma, afincada «en la ladera del monte», que es Jesucristo.

Monte es uno de los nombres de Cristo. «La más principal razón por qué se llama Monte, es por la abundancia, o, digámoslo así, por la preñez riquísima de bienes diferentes que atesora y comprende en sí mismo» (Nombres, 1.1, Monte, 463). Los «montes producen árboles de diferentes maneras, unos que sirven de madera para los edificios, y otros que con sus frutas mantienen la vida... En los montes por la mayor parte se conciben las fuentes y los principios

15. «La lectura de Fr. Luis ofrece numerosos pasajes en que los elementos de la naturaleza sufren continuas transmutaciones metafóricas para expresar otras realidades... No puede abordarse la lectura de Fr. Luis de León sin determinar antes cuidadosamente las líneas básicas de su peculiar idiolecto" (Ricardo SENABRE, Tres estudios sobre Fr. Luis de León, 26-27 y 35. Univ. de Salamanca 1978. 
de los ríos, que naciendo de allí y cayendo en los llanos después, y torciendo el paso por ellos, fertilizan y hermosean las tierras» (Ib.). «Las fuentes y mineros de toda la gracia y virtudes que se derraman por nuestras almas y pechos, y los hacen fértiles, en él tienen su abundante principio; en Él tienen sus raíces, y de Él nacen y crecen con su virtud, y se visten de hermosura y de fruto las hayas altas, y los soberanos cedros y los árboles de la mirra, como dicen los Cantares $(4,14)$, y del incienso: los apóstoles y los mártires y profetas y vírgenes... $\mathrm{Y}$ como el monte alto, en la cumbre, se toca de nubes y las traspasa, y parece que llega hasta el cielo, y en las faldas cría viñas y mieses, y da pastos saludables a los ganados, así lo alto y la cabeza de Cristo es Dios, que traspasa los cielos, y es consejos altísimos de sabiduría, adonde no puede arribar ingenio ninguno mortal; mas lo humilde de él, sus palabras llanas, la vida pobre y sencilla y santísima que, morando entre nosotros, vivió, las obras que como hombre hizo, y las pasiones y dolores que de los hombres y por los hombres sufrió, son pastos de vida para sus fieles ovejas. Allí hallamos el trigo, que esfuerza el corazón de los hombres; y el vino, que les da verdadera alegría; y el óleo, hijo de la oliva y engendrador de la luz, que destierra nuestras tinieblas. El risco, dice el salmo $(103,18)$, es refrigerio de los conejos. $\mathrm{Y}$ en ti, ;oh verdadera guarida de los pobrecitos amedrentados, Cristo Jesús!; y en ti, ;oh amparo dulce y seguro, oh acogida llena de fidelidad!, los afligidos y acosados del mundo nos escondemos. Si vertieren agua las nubes y se abrieren los canales del cielo, y saliendo la mar de madre se anegaren las tierras y sobrepujaren como en el diluvio sobre los montes las aguas, en este Monte, que se asienta sobre la cumbre de todos los montes, no las tememos» ( $I b ., 464-465)$.

En la ladera del Monte, que es Jesucristo en su humanidad, está plantado el huerto de la Iglesia (apóstoles, mártires, profetas, vírgenes...). En ella tiene Fr. Luis, plantado «por su propia mano», su huerto. De la cumbre del monte (a la que ningún mortal puede llegar), de su divinidad, huerto de vida, huerto de huertos, cae presurosa la gracia (fuente), que viste de hermosura y flor los huertos de la ladera; de flor que «muestra en esperanza el fruto cierto» $(I, 45)$, el «fruto cierto» de la salvación. La gracia, que es fuente, es también brisa, «ábrego» que «el huerto orea» $(\mathrm{I}, 56)$ y esparce a la redonda el buen olor de Cristo «para buen ejemplo y gran provecho de otros muchos» (Cantar, 4,16); mientras que el cierzo, viento frío que quema las plantas son los «tiempos ásperos y de tribulación, que encogen y marchitan la virtud» (Ib.), y «el espíritu enemigo, y el sentido de la carne mundanal y ambicioso, tan lejos del calor de la caridad que da vida» $(\operatorname{Job} 37,9){ }^{16}$.

16. El texto de los Nombre sobre el significado traslaticio de la palabra monte lo usó ya Ricardo Senabre en la interpretación de la oda I, (ob. cit., 25-35). En cambio, nunca, que yo sepa, lo han sido los del Cantar, 4, 15-16 y Job 37,9, tan fundamentales para la interpretación simbólica 
¡Admirable Fr. Luis! Capaz de condensar en un verso de insuperable belleza los más arduos problemas teológicos de su tiempo: «ya muestra en esperanza el fruto cierto» $(\mathrm{I}, 45){ }^{17}$. No; lo poético de estos versos no está en la realidad del huerto de La Flecha, sino en el sentido profundo que Fr. Luis, nutrido de clásicos y Biblia, da a esos árboles floridos, suavemente oreados por la brisa. En ellos encuentra simbolizada la libertad que busca, la de una vida auténtica y en paz, lejos de las porfías insidiosas de los hombres. «El sentimiento que, saliendo de Fr. Luis de León, ha ido a elegir el huerto en la ladera del monte, florido y fecundo, es el de la sagrada libertad del alma solitaria y en paz. Nada abstracto, nada especulativo tampoco, sino bien concreto y vivido en el alma personal del poeta. La flor y el fruto entran en esta construcción porque su sentido es la espera segura del poeta. El poeta quiere vivir consigo, a solas, una vida auténtica, y con eso se sentirá cimentado en la seguridad» ${ }^{18}$.

Sí; todo esto es cierto. Pero aún hay más, mucho más. El huerto es, sobre todo, el alma en gracia de Fr. Luis. Una cita del Cantar de los Cantares, que Fr. Luis da en el pasaje antes citado sobre el significado espiritual de la palabra monte, nos introduce, como de la mano, en el interior de ese huerto florido, «jardín cerrado» (Cant 4,12), donde amado y amada se recrean. Fr. Luis, como la esposa, le pide a Dios que aleje de su huerto el hostigo del cierzo, que «quema y abrasa los árboles y las plantas»; pero que «venga el ábrego y sople en este huerto mío con un airecico templado y suave, para que con el calor se despierte el olor, y con el movimiento le lleve y derrame por mil partes, por manera que gocen todos de su suavidad y deleite» (Cant 4,16).

Huerto cerrado y florido de la esposa, situado en la ladera, «a la halda» del monte de Jerusalén, adonde baja el Esposo a recrearse «entre las eras de las plantas olorosas», "cogiendo flores» (Cant 6,1). Huerto eterno del Padre y el Hijo, oreado por el Espíritu, donde «se conciben las fuentes y los principios de los ríos». Jardín inviolado del primer hombre y la primera mujer, por el que «Dios se paseaba tomando el fresco» $(G n 3,8)$. Huerto virginal de María, en el que «halló la Deidad digno reposo» (XXI, 13). Huerto de Getsemaní, «al otro lado del torrente Cedrón» $(J n 18,1)$, fuera de la ciudad, del «mundo este» $(J n 13,1)$, del «mundanal ruido» $(I, 2)$, que es el poder y la riqueza con todas sus secuelas de esclavitud y corrupción. Huerto del monte de la Cru-

de las estrofas sobre el huerto. Un estudio de toda la oda, «desde esta ladera», puede verse en Dámaso, Alonso, Poesía española, Ensayo de métodos y límites estilísticos, 154-159. Edit. Gredos, Madrid 1957.

17. Sobre el tema de la espezanza y la seguridad de salvación, cf. F. SÁnCHEz ArJonA, La certeza de la esperanza cristiana, en los teólogos de la escuela de Salamanca, Roma 1969.

18. Amado Alonso, El ideal clásico de la forma poética, en Materia y forma en poesía, 35. Edit. Gredos. Madrid 1960. Las pp. 33-37 son un bello comentario de la estrofa «del monte en la ladera»... 
cifixión, en el que había «un sepulcro nuevo donde todavía no habían enterrado a nadie» ( $J n 19,41)$ y en él sepultaron a Cristo, huerto de vida, abundoso de «pastos de vida». Huerto de la mañana primera y pura de la Resurrección, nueva creación y humanidad nueva, en el que el esposo se hace el encontradizo con la esposa (Cf. $J n 20,11-18$ ) y la «llama por su nombre» $(J n 10,3)$, y ésta «le sigue, porque conoce su voz» (Jn 10,4), y parte a cumplir el encargo que él le da. Huerto de los sacramentos: del Bautismo, con el agua, que regenera y fertiliza y viste de hermosura y flores, y con el óleo, que engendra la luz, que ahuyenta las tinieblas; y de la Eucaristía, con el pan, que esfuerza a los caminantes, y el vino, que alegra la vida. Huerto de todos los seguidores de Cristo, que en él tienen sus raíces y de su virtud se nutren y por él crecen y dan frutos de obras buenas. Huerto de Fr. Luis, «por su mano» $(I, 42)$ plantado y cultivado en la ladera del Monte, que es la humanidad de Cristo. Huerto eterno del Padre, en la cumbre del Monte, al que Fr. Luis espera llegar, como todos los que ponen su esperanza en Cristo, «con esperanza cierta»; porque «esa esperanza no defrauda» $(\operatorname{Rom} 5,4)$ y, como nadie «podrá privarnos de ese amor de Dios, presente en el Mesías Jesús, Señor nuestro» $(I b ., 8,39)$, «en ningún caso saldré fracasado» $(F l p 1,20)^{19}$.

Huerto exterior y huerto interior, lugar externo y estado espiritual, se funden, pues, en la poesía de Fr. Luis, en una construcción ejemplar y coherente. Aquél remite a éste y éste destiñe a aquél y lo viste de sus propias cualidades. Por no entenderlo así, ha habido quienes se han extraviado en disquisiones sobre si Fr. Luis plantó o no plantó «por su propia mano» el huerto de La Flecha y si eso era o no decoroso con su estado, o sobre lo poco enterado que estaba sobre los riesgos de las cosechas, pues ve ya en la flor «el fruto cierto».

Y todo esto, ¿por qué? ¿Por qué este mundo visible es trasunto de aquel otro invisible? Porque en el invisible están los originales de todas las cosas o ideas ejemplares, que dijo Platón. Las cosas de este mundo y los acontecimientos son meras copias, traslados que Dios hace de los originales que están en su Hijo. Dios «desde toda su eternidad, se pinta y se dibuja en sí mismo, y después, cuando le place, se retrata de fuera. Aquella imagen es el Hijo; el retrato que después hace fuera de sí, son las criaturas, así cada una de ellas, como todas allegadas y juntas. Las cuales, comparadas con la figura que produjo Dios en sí y con la imagen del arte, son como sombras obscuras, y como parte por extremo pequeñas, y como cosas muertas en comparación de la vida... Todo lo que en este mundo inferior nace y se muere, y todo lo que en el cielo se muda y, corriendo siempre en torno, nunca permanece en un ser, en

19. La traducción de los textos bíblicos es la de la Nueva Biblia Española, salvo la de Gn 1,2 , citado en la n. 48 . 
esta imagen de Dios tiene su ser sin mudanza y su vida sin muerte, y es en ella de veras lo que en sí mismo es cuasi de burlas» (Nombres, 1.3, Hijo de Dios, 673-674). Las criaturas son, pues, huellas del creador; voces que hablan de él; sombras de una realidad invisible; revelación y velo al mismo tiempo ${ }^{20}$.

Por eso, Fr. Luis anhela llegar al cielo para contemplar «lo que es y lo que ha sido, / y su principio propio y ascondido» (X, 9-10). Porque en él está «el trasunto, / do vive mejorado / lo que es, lo que será, lo que ha pasado» (VIII, 38-40) ${ }^{21}$. Cristo es el dechado (trasunto) al que Dios mira para sacar las copias (trasunto) de las criaturas. «Aquesta imagen puso las manos en todo cuando Dios lo crió, no solamente porque era ella el dechado a quien miraba el Padre cuando hizo las criaturas, sino porque era dechado vivo y obrador, $y$ que ponía en ejecución el oficio mismo que tiene» (Nombres, 1.3, Hijo de Dios, 675). Allí, en el cielo, en la visión de Dios, contemplará los secretos de la naturaleza, «las causas de todas las cosas y los principios interiores y propios» de cada una, porque allí están a lo vivo (In Psalmum XXVI, Opera, I, 137138. Salmanticae 1891). También en el cielo de Fr. Luis de Granada está mejorado y ennoblecido todo lo que de bueno y bello hay en la tierra. Allí están los prototipos de todo lo que aquí admiramos. «Pues todas estas hermosuras que vemos y otras que no vemos están por muy más excelente manera en el Creador de ellas. Y, según esto, ¿cuál será la bienaventuranza de aquellos que ven todas estas hermosuras en la faz de Dios, con otras infinitas que son propias suyas, que a ninguna criatura fueron comunicadas?» (Obra selecta, 1.117. BAC. Madrid 1952).

20. Cf. OTis H. GreEn, España y la tradición occidental, t. II, 11-41. Edit. Gredos, Madrid 1969. Para una consideración actual de la revelación de Dios por las criaturas, cf. Luis Alonso Schöckel, La Palabra inspirada, 28-35. Edic. Cristiandad, Madrid 1986, 3. a edic. Louis Bou. YER, Le monde et la glorie de Dieu. Ed. du Cert, Paris 1982.

21. Trasunto es «copia o traslado que se saca del original»; en este sentido, el suelo es trasunto del cielo. «Metafóricamente vale figura o representación que imita con propiedad alguna cosa. Lat. Imago, exemplar», se lee en el Diccionario de Autoridades, s.v. trassunto, que pone este ejemplo de Calderón «el sacrificio incruento / de quien fue trasunto Isaac». La realidad es el sacrificio cruento de Cristo; Isaac fue una copia, ejemplar o trasunto, hecho por anticipado. El trasunto remite siempre a otra realidad, a la que se subordina como figura suya. La palabra se mantiene así fiel a su etimología: trasunto (trans-sumir), transportado, tomado de, trasladado de, adquirido de, copiado de... Pero, en el ejemplo de Fr. Luis, «trasunto» es el original, en el que están «mejoradas» las cosas de este suelo, que son las copias. Sin duda, fue el doble significado de ejemplar-copia o traslado, pero también forma o modelo o dechado que sirve de ejemplo (ideas ejemplares) el que contagió a «trasunto» con el significado de «modelo o dechado», además del que tenía de copia o traslado. Que esto fue así se ve claramente en estos versos de la Elegía I de Garcilaso (vv. 283-285): «puesta la vista en aquel gran trasunto / y espejo, do se muestra lo pasado / con lo futuro y lo presente junto». Son la fuente inmediata de los de Fray Luis. 


\section{b) Hados y señales}

Entre los secretos que Fr. Luis espera conocer en el cielo están «las causas de los hados, las señales» $(\mathrm{X}, 55)$. «Señales» son los fenómenos celestes o los acontecimientos extraordinarios, signos visibles de algo oculto o anuncios de que algo grave se avecina. «Aunque la mula tuviera más señales que las que han de preceder al día tremendo, aquí la transformaríamos» ${ }^{22}$. Son, en particular, los astros (signum, sino). «En triste y menguado sino mis padres me engendraron, y en no benigna estrella mi madre me arrojó a la luz del mundo» ${ }^{23}$.

El P. Ángel Custodio Vega, temeroso de que se le tache a Fr. Luis de creer en el influjo de los astros, se apresura a poner una nota aclaratoria: «no creía en los hados o acontecimientos fatales, sino en ciertos hechos que así lo parecen. En esta estrofa y en la siguiente se habla sólo de los fenómenos celestes» ${ }^{24}$. Dejemos a Fr. Luis en las creencias que tenía, sean o no las nuestras. Los astros influyen en la vida del hombre y, por eso, hasta cierto punto puede predecirse el futuro, si se conoce la astrología, dependiendo el acierto de lo acertado que sea el conocimiento. Esto es lo que Fr. Luis creía y esto es lo que habían creído los Santos Padres y doctores que le precedieron, y lo que siguieron creyendo los que vinieron, después de él, hasta bien entrado el siglo XVIII ${ }^{25}$. «Si cría el cielo, cría también la tierra, que es menos que el cielo, y nace y se gobierna dél en cierta manera» (Job 9,9). «Por la luz y las tinieblas y por las moradas de ambas, se entiende también lo de la muerte y la vida, y juntamente sus causas, que son las constelaciones y aspectos celestes en que la luz y la noche viven y moran; por manar en cierta manera dellas el vivir y el morir, el venir a esta luz común o el salir della, dejándola» $(\operatorname{Job} 38,20){ }^{26}$. «Sujetó estas cosas bajas al gobierno de las celestiales, y hizo que las estrellas presidiesen el suelo» (Job 38,33). Para ellos las estrellas estaban regidas por ángeles, pobladas de espíritus celestes, o eran seres vivientes, como antes habían sido dio-

22. Miguel de Cervantes, La Gitanilla, en Novelas Ejemplares, I, 64. Clásicos Castellanos, Espasa-Calpe. Madrid 1969; «¿Cuándo será la señal de tu venida y del fin del mundo?», le preguntan los discípulos a Jesús (Mt 24,3par).

23. Miguel de Cervantes, Los Trabajos de Persiles y Sigismunda, I,2. Obras Completas, 1.531. Aguilar, Madrid 1960. Ya Varrón decía que en astronomía «signa dicuntur eadem, et sidera», porque significan algo (Cf. A. EERnOUT-A. MEILlEt, Dictionnaire etymologique de la langue latine. Histoire de mots, s.v. signum. Edit. Klincksieck, Paris 1979, 4. ${ }^{a}$ edic.) Sobre el vocabulario latino de los signos y presagios, cf. Emilio BENVENISTE, Le vocabulaire des institutions indoeuropéennes, 2, 255-263. Les Edit. de Minut. Paris 1969.

24. Fr. Luis de León, Poesías, 37. Edit. Planeta. Barcelona 1975.

25. Cf. Jean SEznec, Los dioses de la antigüedad en la Edad Media y en el Renacimiento, 41-76. Taurus ediciones. Madrid 1983. Julio CARO BAROJA, Vidas mágicas e Inquisición, vol. II, 147-339. Edic. Taurus. Madrid 1967.

26. También el P. Félix García, en nota a este pasaje de $J o b$, se siente obligado a exculpar a Fr. Luis: su «posible astrologismo no tiene nada que ver con la astrología». 
ses. Un mundo muy distinto del que estudia y explora la astrofísica de nuestros días.

Se trata, sin embargo, de una astrología bautizada, sometida a la ley de la Providencia, que lo gobierna todo. Las «señales» son signos por los que Dios comunica a los hombres su voluntad favorable o adversa, su protección o su castigo para que retornen al orden. Las estrellas influyen en el destino de los hombres. "Quién rige las estrellas / veré, y quién las enciende con hermosas / y eficaces centellas» $(X, 56-58)$. «Si es admirable la hermosura de las estrellas, no menos lo es la eficacia que tienen en influir y producir todas las cosas en este mundo inferior» ${ }^{27}$. Influyen, pero el hombre puede vencer su influjo. Trahunt, non cogunt, se decía: inclinan, no fuerzan; o también: virtudes vencen señales; o vir sapiens dominabitur astris, el sabio dominará las estrellas. Estrelleros, sí; pero ortodoxos.

\section{c) Mundo antiguo, modernidad y siglo $X X$}

El pensamiento antiguo y medieval era simbólico y hay que tener esto muy en cuenta, por muy engorroso e intrincado que a veces nos resulte. De lo contrario, nos exponemos a cercenar de los textos la dimensión que realmente les da sentido: su cara oculta, el meollo o sentencia, como entonces se decía. Agua, tierra, aire, fuego, plantas, piedras, animales, acontecimientos, saberes, números, palabras... Todo era cifra de misterios y a desvelarlos se dedicaban Lucidarios, Lapidarios, Bestiarios, Espejos naturales e historiales, Imágenes del mundo... Asombra el pertinaz ahínco con que aquellos hombres se entregaban al ejercicio de descubrir y establecer relaciones entre este mundo visible y el invisible de los sacramentos, la gracia, la Iglesia, la Virgen o las tres divinas personas ${ }^{28}$. Mundo y trasmundo no están aislados, sino que éste se hace

27. Fr. LuIS DE GRANADA, Obra selecta, 92, edic. cit.

28. Cf. especialmente para el simbolismo en la Edad Media: J. HuizingA, El otono de la Edad media, 277-293. Rev. de Occidente. Madrid 1961, 5. a Edic.; Santiago SEBASTIÁN LÓPEZ, Mensaje del arte medieval. Edic. el Almendro. Córdoba 1984; Pierre-YvEs BADEL, Introduction à la vie littéraire du Moyen Âge, 15-17 y 51-55. Bordas, Paris 1969; Ernst RoBERT CuRTIUs, Literatura europea y Edad Media latina, I, 448-479. FCE, México-Madrid-Buenos Aires, 1976; Alberto VÁRVARO, Literatura románica de la Edad media, 42-66. Edit. Ariel. Barcelona 1983; Hovvard R. PATCH, El otro mundo en la literatura medieval FCE, México-Madrid-Buenos Aires 1983; Paul ZumTHor, Essai de poétique médiéval, 117-140. Edit. du Seuil. Paris 1972; Manuel Guerra, Simbología románica Fundación Universitaria Española, Madrid 1986.

En los siglos XVI y XVII, persistía en los medios espirituales la misma visión y el mismo afán. Del Bto. Alonso de Orozco, en quien hay claros rasgos del dolorismo de la época, se lee: «Tenía grabadas por armas de la nobleza de su amor (en su corazón) las señales de la pasión de Cristo, nuestro bien... Es de maravillar la destreza con que encuentra la alusión y simbolización con la muerte de Cristo, nuestro bien crucificado, juntamente con todos los sucesos de su Pasión... Porque si daba el reloj la hora, le hacía eco en el corazón los golpes de las campanas, como los que herían con los clavos los martillos de los verdugos con que traspasaban los pies y ma- 
presente en aquél, que es como un inmenso libro escrito en clave; en clave simbólica. «Hay que esforzarse por descifrarlo, por desentrañar su gran metáfora, preñada de metáforas parciales, cuyo sentido último ha de coincidir con la verdad revelada» ${ }^{29}$.

La Edad moderna abandonó este camino y comenzó a leer el universo en clave científica, en un lento y difícil proceso de secularización. La cultura clerical, que hasta entonces había dominado vidas y haciendas, mentes y voluntades, incapaz ahora de desmontar el viejo tinglado y renunciar a sus privile-

nos de Jesucristo nuestro Señor [en Memorial del Amor Santo cuenta esto él mismo]. Si miraba a la tierra, consideraba que fue su sepulcro / como él mismo dice / y que en ella nos dejó perpetuo monumento de su memoria para que de él no nos olvidemos jamás. En la noche miraba una cifra adonde leía a Cristo, nuestro Bien, clavado de pies y manos en la cruz, el cual, dice el siervo de Dios, del medio día hizo noche, haciendo tinieblas en la tierra cuando murió; de que deducía tiernas y amorosas consideraciones de cuanto con razón se avergonzaron los ojos del cielo de estar abiertos para un tan crudo y lamentable espectáculo, hallándose ellos resplandecientes cuando los divinos de Cristo se eclipsaban con la muerte turbándose y afeándose con la sangre que vertían las heridas de las penetrantes espinas. Si miraba al sol, le juzgaba por no verdadero, porque sólo lo es el Sol de Justicia, Jesucristo, Redentor nuestro, enclavado en la cruz. En todo cuanto veía y oía encontraba a su Crucifijo, porque todo lo miraba con los ojos tan de su Amado Jesús crucificado, que en todo y por todo le hallaba su enamorado espíritu. De aquí se le originaba el continuo reparo que, en viendo en el suelo algo colorado, se arrodillaba y lo levantaba con gran ternura, pareciéndole que no era bien que padeciese aquel desprecio, lo que se parecía a la sangre de Jesucristo, su amado. Qué escrúpulo tan gigante en la fineza, aunque tan niño para reparo, de que podemos considerar qué escrúpulo haría su amante corazón en ofensas, desmenuzando con tanta delicadeza en amorosas prolijidades. Traía consigo (ordinariamente) cinco piedrecitas con sangre del brazo para que perpetuamente sus ojos se empleasen en ellas para que no se olvidasen las cinco llagas por donde se vertieron los preciosos rubíes de la sangre de nuestro Redentor. Con yerbas amargas disponía su bebida, para que al gustarla le supiese a la de hiel y vinagre que dieron a beber a nuestro Redentor, con cuya consideración satisfacía sus hidrópicos deseos de padecer y crucificarse con su amado Jesucristo. [El corazón es símbolo del monte Calvario. En él, como en la roca, se ha de clavar la cruz]. Para eso pienso yo que la concavidad del corazón quedó a la parte del cielo, para que árbol tan santo, se plantase y se contemplase en él»..., etc..., etc..., etc... (Claudio Burón, ob.cit., c. XVIII, 388-390). Naturalmente, todo esto iba acompañado de ríos de lágrimas, tal como exigía el hombre antiguo. De lo contrario, no había dolor.

Leáse este otro texto, tan extraño ya a nuestra sensibilidad: «puedes contemplar en Dios todas las perfecciones que hallares en cualquier de las criaturas... Has de referir pura y desnudamente a Dios toda virtud y bondad que hallares en la criatura... Conocí yo uno que, viendo una vez un gallo que abría las alas y las sacudía para cantar, sintió verdaderamente que sus entrañas se removieron y se abrieron a Dios para lo amar dulcísimamente, y cosas semejables le acaecían muchas veces con otras criaturas, ca sacaba de toda cosa movimiento del amor a Dios» (Fray Francisco de Osuna, Tercer abecedario espiritual, tratado XVI, c. 9, 486-488. BAC, Madrid 1972).

29. Rafael LAPESA, Símbolos y palabras en el Setenario de Alfonso X, en Estudios de Historia Lingüística española, 232. Paraninfo. Madrid 1985; «El lenguaje de los místicos va caminando de metáfora en metáfora. Una historia del origen y evolución de estas metáforas y una clasificación de su aplicación doctrinal y de sus modalidades estilísticas, nos darían más luz sobre la historia de la espiritualidad mística que muchas disertaciones teológicas» (P. SÁINZ RodRiguez, Espiritualidad española, 302. Rialp. Madrid 1961). Cf. Id.: Antologia de la literatura espiritual española, IV, 657-680 (las metáforas en la literatura espiritual). Univ. Pontificia de SalamancaFundación Univ. Española, Madrid 1985. 
gios, comenzó a ser acorralada por los nuevos conocimientos, hasta ser encerrada en su recinto profesional. El mundo se volvió opaco y la Biblia, libro de todos, se convirtió en propiedad del clero y arcano para iniciados. Las cosas (y, por supuesto, los hombres y su historia) tienen consistencia en sí mismas y en ellas mismas hay que estudiarlas. Ahí se acaba su ser. Son, como se dice, autónomas. Lo demás es pensamiento mágico, noche medieval. La nueva ciencia es la física, que se encarga de tomar posesión del mundo. Los espíritus más discretos hacen reverencias a la Teología, pero a renglón seguido se desentienden de ella, como cosa de otro mundo. Así, Descartes; así, Cervantes. Para colmo, Teología y Espiritualidad comenzaron a caminar cada una por su parte, mirándose mutuamente con desdén.

En adelante, cuando la modernidad cultive el simbolismo, será un simbolismo intramundano. Se descubrirán correspondencias y relaciones múltiples entre los elementos de la naturaleza, y hasta se hará de ella un bosque mágico, poblado de voces y ecos que mutualmente se responden; pero siempre dentro de los confines de este mundo. "La naturaleza es un templo de vivientes columnas, que a veces pronuncian palabras confusas. El hombre pasa entre ellas, como a través de bosques de símbolos que le observan con miradas familiares» ${ }^{30}$. Baudelaire se eleva por encima de los montes y las nubes, del sol y las estrellas, con un ímpetu que recuerda las ascensiones platónicoagustinianas; pero no traspasa las ondas azules del cielo y se queda bañándose gozosamente en ellas. Siempre dentro de este mundo, escuchando «el lenguaje de las flores y de las cosas mudas» ${ }^{31}$. La naturaleza es un templo, pero sin Dios.

Los símbolos religiosos han quedado arrumbados en el desván de las cosas inútiles. Nuestra época es de «depreciación del simbolismo religioso» ${ }^{32}$. «La idea sacramental presupone una interpretación simbólica del mundo, mientras que nuestra visión actual de él es funcional. Consideramos las cosas puramente como cosas, como función del trabajo y la tarea humanos; con este punto de partida es imposible comprender cómo una 'cosa' se convierte en un 'sacramento' ${ }^{33}$. Ha habido círculos religiosos en los que por el afán de estar a la última, que es el mejor modo de no enterarse de nada, hasta molestaba la palabra «espiritualidad» e hicieron de ella tabú. ¡Como si fuera un enriquecimiento sepultar en el olvido las dimensiones más profunduas del hombre!

30. Ch. BAudelaire, Les fleurs du mal, Correspondances, 11. Librairie Arnaud Colin. Paris 1968 .

31. Ib., Elevation, 10-11.

32. Mircea ElIADE, Historia de las creencias y de las ideas religiosas, II, 351. Edic. Cristiandad. Madrid 1979.

33. Joseph RATZINGER, Ser cristiano, 58. Edic. Sígueme. Salamanca 1967. 
Pero la modernidad ya no es nuestro mundo ${ }^{34}$. Los símbolos y la poesía vuelven a ser camino de acceso a realidades de otro modo inacesibles. Desde los más distintos dominios de las ciencias, y la física ha sido pionera, las voces más prestigiosas se levantan contra la reducción a que ha sido sometida la realidad. No toda realidad encaja en los esquemas de la razón especulativa, pero no por eso es menos real. La creencia de que la realidad es totalmente racional ha resultado falsa y se ha evaporado como tantas otras. En esas estamos: braceando en el mar océano, sin modernidad y sin haber descubierto la nueva tierra sobre la que asentar los pies, «en esa grave y sangrienta crisis histórica, la más sangrienta y grave desde el hundimiento del Imperio Romano» ${ }^{35}$. Buena ocasión para redescubrir el valor de los símbolos religiosos, como expresión de experiencias de otro modo inexpresables, sin dar en la manía de ver símbolos en todo. Lo que se gane en sobriedad se ganará también en intensidad ${ }^{36}$.

\section{d) Algunos ejemplos}

Mas vengamos a algunas aplicaciones concretas que Négrier hace del simbolismo en Fr. Luis.

\section{d.1) La rueda que huye más del suelo}

En la oda X, Fr. Luis desea ardientemente «volar al cielo» para poder contemplar desde él, «en la rueda / que huye más del suelo, / la verdad pura, sin velo" (2-5).

«La rueda que huye más del suelo» no es la del sol naciente, que por la mañana se levanta sobre el horizonte y avanza hasta tocar la cumbre del cielo al mediodía, como se dice en la p. 52 y se repite en la notá 27 [(a ella se refieren estos versos: «y de su esfera cuando / la cumbre toca altísimo subido / el sol» (XVIII, 21-23)], sino el «cielo», nombrado en el v. 2; es decir, el empíreo o mansión de los bienaventurados, la rueda que está más lejos del suelo. Al final

34. . El primero en advertirlo fue Ortega y Gasset, madrugador en esto como en todo. Cf. Nada «moderno» $y$ «muy siglo $X X$ », en El espectador, I, 26-31. Col. Austral, Espasa-Calpe. Madrid 1966; artículo publicado en 1916; Prólogos a la «Biblioteca de Ideas del siglo XX», en Meditación de la técnica, 132-141. Col. Austral, Espasa-Calpe. Madrid 1965 y, en general, toda su inmensa obra; Romano GuARDINI, El ocaso de la Edad Moderna, en Obras de Romano Guardini, I, 29-120. Edic. Cristiandad. Madrid 1981; Xavier ZUBIRI, Nuestra situación intelectual, en Naturaleza, Historia, Dios, 3-31. Edit. Nacional. Madrid 1978; Julián MARías, Introducción a la filosofía, 35-86 (Esquema de nuestra situación). Rev. de Occidente 1976, 12. ${ }^{a}$ edic.; el libro de Pedro Laín EnTralgo, La Espera y la esperanza, y los conocidos libros de Spengler, Berdiaeff, Jaspers y Huizinga sobre el tema.

35. Pedro Lain Entralgo, La espera y la esperanza, 279. Alianza edit. Madrid 1984, 2. ${ }^{\text {a }}$ edic.

36. Una reflexión actual sobre el símbolo puede leerse en Conceptos fundamentales de pastoral (obra de varios autores), s.v. Símbolo, artículo de Juan MATEos, 961-971. Edic. Cristiandad 1983. Con breve, pero excelente bibliografía. 

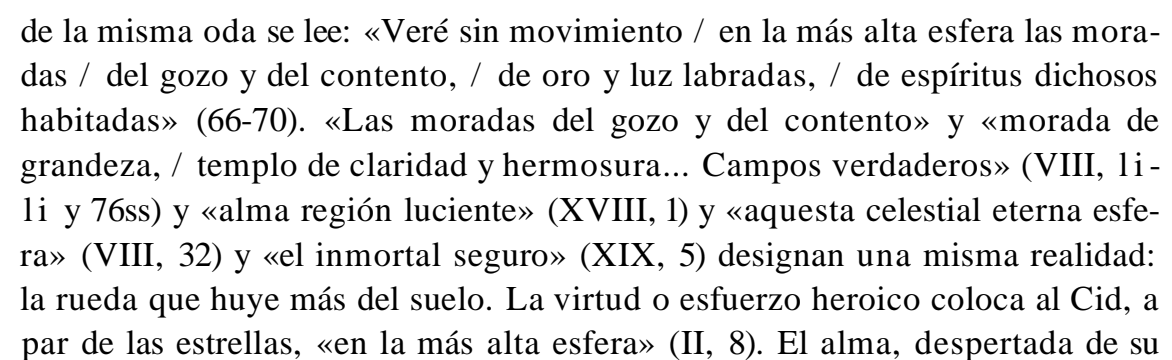

ás $\mathrm{f}$

f $\mathrm{q} \tilde{\mathrm{n}}$

v

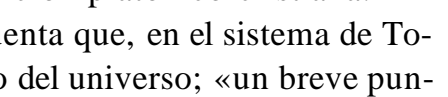

m o,

un $\mathrm{i}$

ú
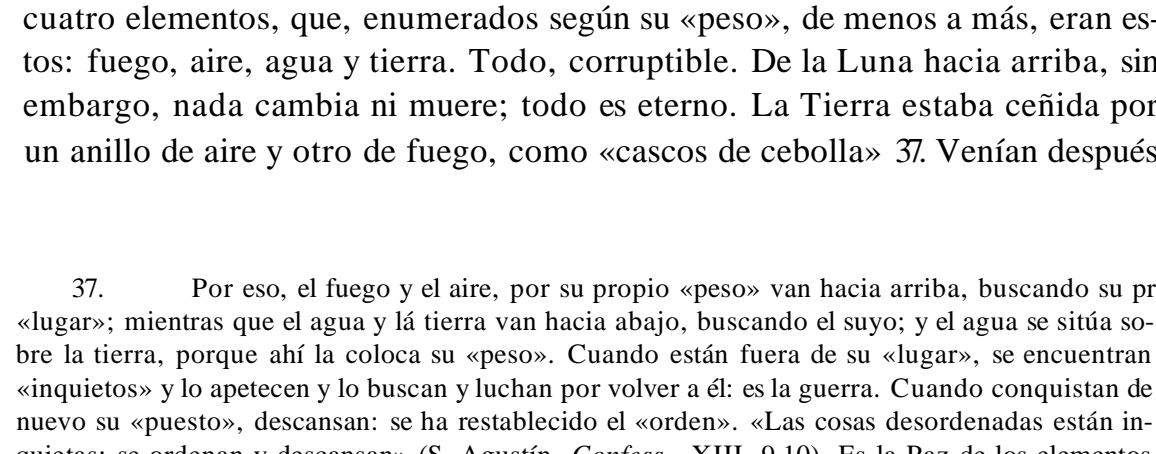

$0<$

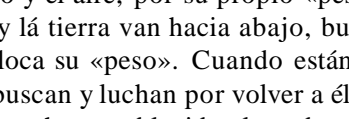
c é :

(S. A ${ }^{\mathrm{b}}$ Conf ss., $\mathrm{X} \quad \stackrel{\mathrm{L}}{9}$ 10). $\mathrm{E}$

m

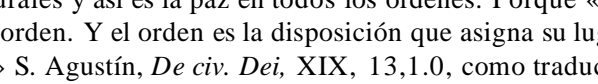
585). D

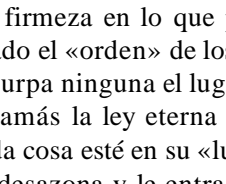

$$
\text { m e é }
$$

m

g
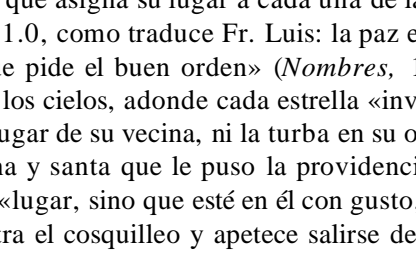
las siete esferas celestes. De dentro hacia afuera eran éstas: la Luna, Mercurio, Venus, el Sol, Marte, Júpiter y Saturno. Por estar en medio, el Sol era el príncipe y señor de las otras esferas, a las que comunicaba su luz y calor. Venían a continuación los tres cielos concéntricos, que lo envolvían todo. Esta distinción rigurosa entre cielos y esferas no se mantenía de ordinario en el lenguaje. A las esferas se las llamaba también cielos; y a los cielos, esferas. Los cielos propiamente dichos eran estos tres: el firmamento o cielo de las estrellas fijas, llamado también octavo cielo u octava esfera (la «ochava esfera» de los textos medievales); el cielo cristalino de las aguas, noveno cielo o novena esfera, donde estaba el zodíaco [«las soberanas aguas / del aire en la región quién las sostiene» (X, 31-32); «encima de los cielos desplegados / al agua diste asiento» (traducción del Salmo 103, 5-6)]; el Primum Mobile, décimo cielo o décima esfera. Por fin, sobre todos ellos, el cielo empíreo, que de designar la zona del fuego y de las estrellas puras y eternas pasó a designar la morada de Dios, fuego puro y eterno, y de sus elegidos, las «moradas de oro y luz labradas» (X, 69).

Dios atrae hacia sí, como atrae el amado al amante, al décimo cielo o Primum mobile. «La causa final mueve en cuanto que es amada, mientras que todas las demás cosas mueven al ser movidas» ${ }^{38}$. Dios mueve sin ser movido. Es el famoso Motor inmóvil o primer Motor de las vías de Sto. Tomás para demostrar la existencia de Dios. "Ansí como dicen que el cielo impíreo - adonde está nuestro Señor- no se mueve como los demás» ${ }^{39}$. El décimo cielo, al ser atraído por Dios, entra en movimiento y arrebata en pos de sí las esferas. Por

su «lugar» natural, su «peso», afinidad, simpatía, inclinación innata, ínsita en ellas por naturaleza. Si cl amor es lo que mueve al hombre y creemos en todo lo anteriormente dicho, metafóricamente se puede decir que «el amor es mi peso; es él quien me lleva adondequiera que soy llevado» (S. Agustín, Confess., XIII, 9,10). Como compuesto físico, el hombre tiene su «lugar» natural, como las demás cosas, y hacia él es llevado por su «peso», cuando está fuera de él; pero el hombre, ser espiritual, tiene que tener también su «lugar» y llevarlo hacia él su «peso». El hombre anda desasosegado e inquieto, sin encontrar descanso en nada de este mundo; luego es que no está aquí su «lugar». La fe da la solución de este enigma: «nos hiciste, Señor, para ti; y nuestro corazón está inquieto hasta que descanse en ti» (Id., Confess., I, 1,1). Nuestro «peso» nos lleva hacia Dios, porque él es nuestro «lugar». Sólo en él hallaremos «reposo»; sólo cuando estemos en él, estaremos «ordenados».

Hay aquí intuiciones sobre maneras profundas, de origen platónico (recuérdese el famoso texto sobre el amor en el Banquete, 203-204), en torno a Dios, el amor y la inquietud del hombre, pero habría que limpiarlas de las adherencias de los «pesos» y «lugares» naturales, que para nosotros, no para ellos, las ocultan y enturbian. Una reflexión actual sobre estos temas, desde la «realidad radical», que es para cada uno su propia vida, puede leerse en J. GómEz CAFFARENA, Metafísica fundamental, tercera parte, 165-273. Edic. Cristiandad. Madrid 1983.

38. Aristóteles, Metafísica, 1.072 b. Edic. trilingüe por Valentín GARCíA YEBRA, Edit. Gredos 1970.

39. Sta. Teresa, Moradas, 7,2,11. Obras Completas, 442. BAC. Madrid 1979, $6 .^{\mathrm{a}}$ edic. $^{2}$ 
eso, pudo escribir Dante: «el amor mueve el Sol y los demás astros» ${ }^{40}$. Había, pues, dos clases de movimientos celestes: «el arrebatado y los naturales» (X, 53-54). El Primum mobile «arrebata» tras él las esferas, que entran en movimiento, siguiendo cada una su órbita o «rueda», a la velocidad que le está marcada por el orden «natural», orden divino e inviolable. Fr. Luis contempla, en la noche estrellada, las esferas celestes, «su movimiento cierto, / sus pasos desiguales, / y en proporción concorde tan iguales» (VIII, 43-45), y ve cómo «con paso callado, el cielo, vueltas dando, / las horas del vivir le va hurtando» (VIII, 23-25). «Dióles (Dios) tanta constancia en sus movimientos, que desde que los crió, nunca han variado un punto de aquella regla y orden que al principio les puso ${ }^{41}$.

No es posible entender nada de esto, si no se tiene en cuenta que cielos y esferas fueron durante siglos dioses. Desdivinizados posteriormente, continuaron hasta bien entrada la Edad Moderna regidos por inteligencias angélicas. Y ésta era la opinión común, no la de unas cuantas mentes delirantes. Los oficiales que de los cuatro elementos «fabrican todas las cosas son los cielos, con sus planetas y estrellas. Porque dado caso que Dios sea la primera causa que mueve todas las causas, pero estos cuerpos, con las inteligencias que los mueven, son los principales instrumentos de que él se sirve para el gobierno de este mundo inferior» ${ }^{42}$. Una densa multitud de ángeles y demonios, perfectamente jerarquizada, poblaba el espacio terrestre y extraterrestre ${ }^{43}$.

40. Otis H. GREen, España y la tradición occidental, t. II, 42-64. Edic. Gredos. Madrid 1969; Antonio HuRTADo TORRES, La astrología en la literatura del siglo de Oro, 31-62. Instituto de Estudios Alicantinos 1984; José María LÓPEZ Piñero, Ciencia y técnica en la sociedad española de los siglos XVI y XVII, 178-196. Edit. Labor. Barcelona 1979; Alexandre KoYrE, Du monde clos a l'univers infini, 17-43. Edit. Gallimard. Paris 1973; C. S. Levvis, La imagen del mundo, 69-91. Antoni Bosch, editor. Barcelona 1980.

41. Fr. Luis de GranadA, Obra selecta, 91, edic. cit. En esta distinción entre movimiento «arrebatado» y «naturales» sigo la interpretación de Rafael Lapesa: Las odas de Fr. Luis de León a Felipe Ruiz, en De la Edad Media a nuestros días, 188. Edit. Gredos, Madrid 1967. Cita este texto de Herrera: «el cielo propiamente es uno solo, los demás se llaman globos y orbes, i es aquel que arrebata con su movimiento principal todas las otras esferas y orbes» (Anotaciones a las obras de Garcilaso, 1580, p. 335). En las ediciones que traen notas a este pasaje se interpreta el movimiento «arrebatado» por el movimiento rápido de los meteoros, cometas y estrellas fugaces.

42. Fr. Luis de Granada, Ob. cit., 90.

43. La cadena o grados del ser es otra de las claves del pensamiento antiguo. Cf. OTIS H. GREEN, España y la tradición occidental, II, 17-41. Edit. Gredos. Madrid 1969. El libro clásico sobre el tema es el de Arthur O. Lovejoy, The Great Chain of Being, Cambridge, Mass 1948. 


\section{d.2) El nivel y la plomada}

Dice Fr. Luis:

Entonces veré cómo

el divino poder echó el cimiento

tan a nivel y plomo,

do estable y firme asiento

posee el pesadísimo elemento.

$$
(\mathrm{X}, 11-15)^{44} \text {. }
$$

Comenta Négrier: «el nivel y la plomada evocados por el autor en el verso 13 son literalmente (símbolos) externos a la cosmología, al ser utensilios y no fenómenos naturales; no son, sin embargo, extraños a ella, en la medida en que su estructura, su modulación y su función se asemejan, en virtud de las leyes de la analogía, a las estructuras, modalidad y función de ciertos símbolos cósmicos» (p. 49). En la nota 28 añade: «la mención de estas dos herramientas debe atraer la atención sobre el esoterismo contenido en este poema». El lector debe «encontrar los símbolos cosmológicos que pueden inducir a la meditación de los fundamentos universales de la tradición».

No hay por qué entrar por caminos ocultos, cuando tenemos la explicación del mismo Fr. Luis. Leemos en su traducción del Libro de Job: «¿Quién puso medidas sobre la tierra, si lo sabes? ¿O quién extendió sobre ella emplomada? ¿Sobre qué se afirmaron sus apoyos? O a quién puso la piedra de su clave?». Y comenta: Habla de la tierra «a semejanza de un soberbio edificio de los que los hombres hacen, y ansí nombra los niveles y las plomadas, y los cordeles y las demás partes y instrumentos del arte» (Job 38,6). Recrea el texto en verso y dice: «¿A dónde estabas, dime, al punto y hora / que a plomo cimentaba yo la tierra? ¿Quién hizo por medida llano y sierra? / ¿Quién levantó nivel, colgó plomada / en todo lo que el ancho suelo encierra? / ¿Qué apoyos, dime, tiene?; ¿en qué fundada / está su redondez?; ¿por cúya mano / la piedra de la clave fue asentada?».

\section{d.3) El «estable y firme asiento»}

Comenta Négrier: «el autor cita el «eterno asiento», que no es sino la Osa Menor, cuyo dibujo, si se unen hábilmente con una raya las siete estrellas que la componen, forma, entre otros, el trazado de una silla, símbolo particularmente denso que la tradición taoísta llamó «la silla del olvido» y que dio la fi-

44. El «pesadísimo elemento» es la tierra, el más pesado de los cuatro elementos, como queda dicho. «Pesadísimo» es un superlativo relativo, remedo de la construcción latina. Cf. Rafael LAPESA, El cultismo en la poesía de Fr. Luis de León, en Poetas y prosistas de ayer y de hoy, 125-126. Edit. Gredos. Madrid 1977. 
gura del «trono de Dios» en numerosas páginas del Antiguo Testamento» (p. 51).

Leamos a Fr. Luis: «Fundó la tierra sobre cimientos firmes, adonde permanece y nunca se mueve» (Nombres, 1.I, Padre del siglo futuro, 505, comentario al salmo 103, 11-12: las tierras sobre asientos duraderos / mantienes de contino). «¿Dónde eras al fundar yo la tierra? Cuando yo criaba y cimentaba la tierra... Cuando ponía yo a la tierra cimientos... Le pregunta de la tierra que halla y de sus cimientos que cada día descubre, si sabe o entiende cómo se pusieron en la manera como la tienen en pie. Que a la verdad es caso maravilloso extrañamente y secreto, que cuerpo y pesadumbre tan grande se sustente en el aire, que la cerca a la redonda y del todo» $(\mathrm{Job} 38,4)$.

Está claro que el «estable y firme asiento» de la tierra no tiene nada que ver con la Osa Menor, ni en su tenor literal ni simbólicamente. La tierra con la firmeza de sus cimientos y en medio de los mares es símbolo de la Iglesia, como explica Fr. Luis comentando el salmo 103: «El cuerpo firme y macizo de la Iglesia, que ocupó la redondez de la tierra, recibió asiento por mano de Dios en el fundamento no mudable, que es Cristo, en quien permanecerá con eterna firmeza» (Nombres, 505) ${ }^{45}$.

45. El autor sigue la lectura del P. Ángel Custodio Vega: «estable, eterno asiento», autorizada por algunos códices. Pero otros autorizan a leer: «estable y firme asiento». La razón del P. Custodio Vega no convence: «estable y firme, parece una verdadera sinonimia, que el autor trató de corregir». No lo parece, lo es. Se trata de una reduplicación, con la que el adjetivo queda elevado al grado superlativo: el asiento de la tierra es «firmísimo», firme en extremo, que es en lo que insisten los textos en prosa por otros procedimientos. Según Aristóteles, el mundo se dividía en dos regiones: la naturaleza o mundo sublunar y el cielo o mundo supralunar. Aquélla es la región donde todo cambia, se corrompe y muere; en éste, en cambio, no hay novedad y corrupción, todo es eterno (Cf. Aristóteles, Metafísica 1072 b; C.S. Levvis, La imagen del mundo, 2-3, edic. cit.). Lo que hay y sucede en la tierra es efímero. Sus cimientos, sin embargo, son duraderos, «firmes», capaces de sustentar la tierra siglos y siglos. Dios mismo puso «la piedra de su clave». En comparación con la precariedad de lo demás, cabe decir: «las inmortales columnas do la tierra está fundada» (X, 16-17); pero llamar «eternos» los cimientos sería demasiado y fuera de la mentalidad en la que aquellos hombres estaban. El epíteto se reserva para los elementos celestes: para el empíreo, por supuesto, pero también para las otras esferas: «aquesta celestial eterna esfera» (VIII, 32); «aquestos replandores eternales» (VIII, 42); «este fuego eterno» (el Sol) (X, 61). «Eterno» se dice, y con razón, del cimiento que es Cristo para su Iglesia: «no mudable», «eterna firmeza», que dice Fr. Luis. Sin embargo, como aliquando etiam bonus dormitat Homerus, bien pudo escribir «eterno». ¿O habrá un cruce entre la tierra, cuyos cimientos son «firmes», y la Iglesia, por aquella simbolizada, cuyos cimientos son «eternos»? A continuación se habla de «las inmortales / columnas do la tierra está fundada» (X, 16-17). Inmortal, además de significar «no sujeto a muerte», significa también «lo que dura tiempo indefinido: «por ençarecimiento decimos de la cosa que dura mucho ser inmortal», dice Covarrubias en su Diccionario, y éste es evidentemente el significado que aquí tiene. Símbólicamente haría pensar en los apóstoles, con el primer significado.

En la poesía, la tierra se asienta sobre columnas; en $J o b$, en el aire, que la cerca a la redonda. No nos extrañemos de esta convivencia de sistemas contradictorios. Se daba entonces, y a ella le ha dedicado Otis $\mathrm{H}$. Green el primer capítulo del tomo I de su citada obra, y se da también ahora, por desgracia. 


\section{d.4.) Las lindes y señales del mar}

Dice Fr. Luis:

Veré las inmortales

columnas do la tierra está fundada, las lindes y señales

con que a la mar airada

la Providencia tiene aprisionada.

$(\mathrm{X}, 16-20)$

Comenta Négrier: las lindes y señales «son las constelaciones boreales situadas por encima del trópico de Cáncer, las cuales jamás absorbe el horizonte (el mar para nuestro autor) y así parece que dominan la fuerza del mar» (p. 51).

Leamos de nuevo a Fr. Luis: a la voz de Dios, los mares se retiraron y dejaron descubierta la tierra; «se apartaron a su lugar adonde guardan continuamente su puesto» (Nombres, 505); «no pasarán las calles. / Las calles que les diste y los linderos, / ni anegarán las tierras», dice en la traducción del salmo 103, 20-22. «Y rodeéle con términos y púsele cerrojo y puertas. Y dije: hasta aquí vendrás, y no añadirás; aquí quebrantarás levantamiento de olas tuyas. $\mathrm{Y}$ en el mar es maravilloso mucho el no derramarse en la tierra anegándola, y siendo ansí que la cubría toda al principio, haber descubierto parte de ella por mandado de Dios; y siendo tantas sus aguas y tan furiosas sus olas, no tornar cada hora a cubrirla y quebrantar tanta furia en un poco de arena a la orilla... No hay cerraduras tan fuertes, ni muelles tan firmes que ansí le tuvieran cerrado, como lo tiene agora la raya que Dios le ha puesto en la arena. Cuando él lo cubría todo y a él las tinieblas, le recogí y reduje a término cierto, y le acorté las riendas y enfrené su lozanía para que se detuviese... Los términos que le puso, y el cerrojo y puertas en que le cerró, es la ley y decreto suyo que le ordenó... El cual mandamiento retrujo entonces y tiene hasta agora enfrenadas las mares... Muestra Dios su poder sobre todo y el rendimiento de las criaturas» (Job 38, 8-10). Y traduce en verso: "Y ley le establecí que siempre dura, / y púsele firmísimos candados, / y puertas con eterna cerradura. / Y ven, dije, hasta aquí, los situados / límites no traspases; aquí sean / los bríos de tus olas quebrantados». Al principio, el agua cubría la tierra entera. Su «peso» o «gravedad» la llevaba a su «lugar» natural: el agua encima y la tierra debajo. Pero mandó Dios que las aguas se retiraran, dejando descubierta parte de la tierra para servicio del hombre, y las aguas se retiraron. Es verdad que se revuelven como caballos enfrenados, pero nunca romperán las riendas que Dios les ha puesto y un poco de arena bastará a quebrantar su furia. El mar queda sometido a dos leyes naturales contradictorias - ocupar y desocupar la tierra-, pero 
no se veía inconveniente en ello: los caminos de Dios son inexcrutables (cf. Rom 11,33$)^{46}$.

Siguiendo sus hábitos mentales de leer a través del universo las realidades

46. Compárese con este texto de Fr. Luis de Granada: El agua, «al principio de la creación, cubría toda la tierra, como el elemento del aire a esa misma agua. Mas porque de esta manera no se podía habitar la tierra, el Criador, que todo este mundo criaba para servicio del hombre, así como al hombre para sí, mandó que se juntasen todas las aguas en un lugar, que fue el mar Océano, y que se descubriese la tierra para nuestra habitación; y asi se hizo, sacando el agua de su natural lugar, que era estar sobre la tierra, y recogiéndola en otro» (Obra selecta, 104, edic. cit.). «Y, cierto, es cosa de admiración que corriendo todos los elementos con tan gran ímpetu a sus lugares naturales, y siendo natural lugar del agua estar sobre todo el cuerpo de la tierra y tenerla cubierta, haberla Dios con sola su palabra sacado de este lugar, y conservándola tantos mil años fuera de él, sin usurpar ella un paso del espacio que le señaló. (Lo cual es) para confundir la desobediencia y desacato de los hombres, vista la obediencia de las criaturas insensibles» (Ib., 105-106).

Por su inclinación natural, ley de Dios, los mares tienen que anegar la tierra. ¿Por qué no lo hacen? Porque Dios les ha dado otra ley, según la cual tienen que dejar descubierta parte de ella; pero les ha dado ésta sin quitarles aquélla. Es éste uno de esos casos en que, a poco que se apriete, saltan las contradicciones. El mar ve escrita la ley de Dios en los límites que le ha puesto en la arena y ¿por qué no la ve en el «peso» que le empuja a cubrir la tierra? ¿O es que ésta no es ley de Dios? Saltarse aquélla sería desobediencia, ¿y no lo es no cumplir ésta? Parece como si todo lo que han dicho sobre el «peso» y el «lugar» naturales, al llegar aquí se les olvidara. La coherencia del sistema se resiente, al confluir en él dos tradiciones opuestas: el relato bíblico de la creación y la teoria, al parecer de origen griego, del «lugar» natural de cada cosa. En el libro de la Sabiduría, se dice de Dios: «todo lo tenías predispuesto con peso, número y medida», pero parece que la fórmula es originalmente griega (Cf. Ernst ROBERT CURTIUs, Literatura europea y Edad Media lati$n a, \mathrm{t}$. II, 705, edic. cit., con bibliografía).

Nótese, aunque sea de pasada, que al describir el mar y sus límites y ponderar su obediencia al Creador, los dos Luises hablan de oídas, por lecturas, no por observación directa. La naturaraleza es transparencia de Dios, sombra y vislumbre. No hay que detenerse en ella. Lo que importa es Dios, la realidad vislumbrada. Por la naturaleza hay que ir de vuelo, como diría S. Juan de la Cruz. Es como si en realidad fuera solo un pretexto para hablar de Dios, de su poder y bondad (cf. Rom 1, 19-20). Hacer otra cosa sería cambiar los papeles, darle al mundo un valor que no tiene. Se describe la naturaleza aprendida en los libros; aun en los casos en que hay elementos reales, han sido pasados previamente por el tamiz de las lecturas. ¿Es real el paisaje de S. Juan de la Cruz o bíblico, con aportaciones de la tradición posterior sobre el «lugar ameno»? Lo cual no disminuye en nada el valor de sus creaciones. Simpiemente es decir lo que no hay que buscar en ellas: la descripción de la naturaleza contemplada en sí misma. A través del blanco de la naturaleza, sus flechas van disparadas hacia Dios.

Si en los océanos hay islas, prosigue Fr. Luis de Granada, y no son tragadas por el mar, algún motivo tendrá la Providencia. Es lo que ocurre con la isleta despoblada de santa Elena, camino de las Indias Orientales, puesta por Dios como venta bien provista de agua dulce, pescado, caza y frutas para solaz y descanso de los navegantes. Y con no ser «más que una cáscara de nuez» en medio de las ondas bravas, se mantiene incólume. «Y lo que más nos maravilla es cómo se levanta aquel pezón de tierra sobre que está fundada la isla, desde el abismo profundo del agua hasta la cumbre de ella, sin que tantos mares lo hayan consumido y gastado... ¿Quién no adorará aquí la omnipotencia y providencia del Criador, que así puede fundar y asegurar lo que quiere? Éste es, pues, el freno que él puso a este gran cuerpo de la mar para que no cubra la tierra: y cuando corre impetuosamente contra la arena, teme llegar a los términos señalados, y viendo allí escrita la ley que le fue puesta, da la vuelta a manera de caballo furioso y rebelde, que con la fuerza del freno para y vuelve hacia atrás, aunque no quiera» ( $I b ., 106$ : se ve que la obediencia del mar no es tan perfecta como se nos había dicho). 
invisibles, el mar se le convierte a Fr. Luis en símbolo de la gentilidad, en medio de la cual surgió la tierra, símbolo de la Iglesia, con sus montes, que son los obispos, y sus valles, que son los laicos. El mar jamás la anegará. También a este mar le ha puesto Dios lindes y señales. Asentada sobre la roca de «eterna firmeza», que es Cristo, «en su principio la cubría y como anegaba la gentilidad, y aquel mar grande y tempestuoso de tiranos y de ídolos la tenían casi sumida; mas sacóla Dios a luz con la palabra de su virtud, y arredró de ella la amargura y violencia de aquellas obras, y quebrólas todas en la flaqueza de una arena menuda, con lo cual descubrió su forma y su concierto la Iglesia, alta en los obispos y ministros espirituales, y en los fieles legos humildes, humilde. Y, como dice David, subieron sus montes y parecieron en lo hondo sus valles» (Nombres, 1.1, Padre de siglo futuro, 505, la cita es del salmo 103,8). Yo no encuentro en las obras de Fr. Luis otro simbolismo de «las lindes y señales del mar» más que éste. $\mathrm{Y}$ en la oda $\mathrm{X}$ no se trata de sentido simbólico, sino del mar real. Entre lo secretos de la naturaleza que Fr. Luis espera conocer ${ }^{47}$ está el de las lindes y señales del mar: cómo un poco de arena puede quebrantar su furia ${ }^{48}$.

\section{d.5) Las dos Osas}

Cuando llegue al cielo, Fr. Luis verá por qué están las dos Osas de bañarse en el mar siempre medrosas

$$
(\mathrm{X}, 59-60)
$$

Comenta Négrier: las dos Osas, Mayor y Menor, «en virtud de la elíptica no desaparecen jamás del horizonte, permaneciendo siempre visibles para los habitantes del hemisferio boreal. Por lo mismo, se comprende que la significación de las dos Osas es inseparable de la relación dinámica que tienen con el horizonte (el mar para nuestro autor)» (p. 52).

Los dos versos de Fr. Luis son, como se sabe, traducción de otros de Virgilio. El sentido literal está claro: mientras otras estrellas, con el girar de los cielos, desaparecen del horizonte, es decir, se hunden y bañan, según parece,

47. Nótese: espera conocerlos en el otro mundo, no en éste, que eso sería audacia imperdonable; en esta vida, la naturaleza se contempla como obra del Creador, no se indaga.

48. «Descubrió su forma y su concierto la Iglesia». La Iglesia, en sus orígenes, era como una isla en medio del mar de la gentilidad. El Océano es lo informe, lo indiferenciado, lo amargo y violento, la noche tenebrosa, el terror, el abismo oscuro y profundo de aguas revueltas y pavorosas, «agitadas por un ventarrón de todos los diablos» $(G n 1,2)$. La isla que aparece repentinamente en medio de las aguas es lo formado, el cosmos, el orden, lo diferenciado, la seguridad y la esperanza, el día alegre y tranquilo. (Cf. MIRCEA ElIADE, Tratado de historia de las religiones, 178-200. Edic. Era. México 1964; Id.: Imágenes y símbolos, 165-185. Edic. Taurus. Madrid 1979, 3. ${ }^{a}$ edic.). Los dos sobre los símbolos acuáticos. 
en el mar, las dos Osas se acercan, pero nunca desaparecen, como si tuvieran miedo de bañarse en él. En la traducción en verso que hizo de las Geórgicas dice: «las Osas que en el mar nunca el pie frío / lanzaron» (I, 444-445). Como huía la Galatea de Gil Polo, «al ver venir las olas».

Si en los «cielos, que son los apóstoles y los sagrados doctores y los demás santos (Nombres, 505), Fr. Luis vio a algunos de estos simbolizados por las dos Osas, no lo sé. En todo caso, me parece que no es por donde anda Négrier donde hay que buscar. En Job, llama a la Osa (a las dos) Sietestrello y Arcturo, traduce los versos de Virgilio y se limita a constatar que es siempre visible. Como en un poema o en una sinfonía hay partes neutras, sin relieve, que, por lo mismo, colaboran al realce de las otras, así también en el mundo había elementos que carecían de significación traslaticia. El mundo visible era símbolo, no alegoría, del invisible.

\section{e) Comprensión de los símbolos usados por Fr. Luis}

¿Esoterismo en Fr. Luis? Puede ser, pero hay que probarlo. Los símbolos que él usa se explican, en primer lugar, con otros textos de sus obras, españolas y latinas. Hay que explicar a Fr. Luis por él mismo. Luego, con textos de autores españoles coetáneos, especialmente de los espirituales, herederos de la misma tradición cristiana, que tiene en san Agustín su luminar mayor y en la Biblia su hontanar siempre inexhausto. A todo esto hay que añadir sus siempre bien amados clásicos griegos y latinos. Muchos de estos símbolos son expresión de experiencias universales y hunden sus raíces en la tierra nutricia de los sueños, anhelos y preocupaciones que a todos nos alimenta, encontrándose ya en los orígenes mismos de las religiones arcaicas. Habrá que tener también esto en cuenta para comprenderlos adecuadamente, aunque Fr. Luis no fuera ya consciente de ello. Todo lo que sea pasar de aquí hay que demostrarlo, no suponerlo.

\section{LA TRADUCCIÓN}

Patrick Négrier sigue en la traducción el texto de la edición del P. Ángel Custodio Vega, «monumental y precisa» (p. 26), pero a veces, «por intuición» prefiere el texto de Merino o el de Llobera. Traduce las treinta cuatro poesías que figuran en esta edición, siendo la primera tan completa en francés: las veintitrés consideradas como originales por todos los editores, seis imitaciones (de Petrarca, Juan de la Casa, Pedro Bembo, de diversos y dos de Horacio) y los cinco sonetos. Ha traducido «lo más literalmente posible» (p. 27). A los nombres propios desusados de lugares y personas les da «un equivalente que los haga comprensibles y permita una lectura ininterrumpida». A la traducción le siguen unas breves notas esclarecedoras. 
A partir de ahora, pueden leerse en francés todas las poesías de Fr. Luis, lo cual no deja de ser un acontecimiento para todos los estudiosos del poeta. Esta traducción viene a sumarse a la que anteriormente había hecho de las veintitrés poesías originales Bernard Sesé. Como dice éste en el prólogo: «es el conjunto más completo y fiel de que dispone el lector francés. Tal empresa no había sido intentada antes de ahora: merece que la saludemos reconocidos» (p. 19).

Algún pasaje difícil pudiera aquilatarse más. En la oda IX, cebado no significa «atracado de comida», sino «untado para que sirva de cebo», y la miel no llena el vaso: «no te engañe el vaso dorado ni cebado (untado como cebo) con la miel sabrosa en el borde» ${ }^{49}$. Verdad es que las notas de las distintas ediciones no ayudan mucho a la interpretación de esta oda. En la nota 25, correspondiente a ella, se dice que está dedicada a Querinto - así figura en la mayoría de las ediciones - y añade: «personaje sobre el que apenas tenemos noticias». Ni muchas ni pocas. No tenemos ninguna. En realidad, es un personaje ficticio, tomado de las elegías de Tibulo; un joven al que la apasionada Sulpicia, como sirena, desea atraer hacia sí. Las viejas ediciones de Tibulo titulaban «ad Cherintum» ${ }^{50}$.

Sí; hay que agradecer a P. Négrier su trabajo logrado sobre Fr. Luis. Y, sin embargo... Los textos literarios son intraducibles y esto hay que tenerlo en cuenta. La imposibilidad es aún más evidente cuando se trata de textos poéticos. Fondo y forma son distintos, pero inseparables. La forma no es una mera vestidura externa del fondo (cambiemos el lenguaje, si se ha quedado arcaico, dicen ingenuamente algunos renovadores posconciliares), de modo que pueda prescindirse alegremente de ella sin que éste quede gravemente deteriorado. $\mathrm{El}$ fondo está tan inextricablemente tejido con la forma, que destruida o alterada ésta, se altera o destruye aquél. Cambiado nuestro lenguaje sobre Dios, éste no quedará afectado, como es evidente; pero también es evidente, y la reflexión lingüística no deja lugar a dudas, que nuestra imagen de Dios y nuestras actitudes en relación con él serán otras.

Hace años que, frente al principio Saussureano de la arbitrariedad del

49. Cf. Rafael LAPESA, El cultismo en la poesía de Fr. Luis de León, ob. cit., 131.

50. Cf. Francisco Rico, Primera cuarentena y tratado general de Literatura, Barcelona, El Festín de Esopo 1982; la última edición de las Poesías de Fr. Luis de León, por Darío FernándezMorera y Germán Bleiberg traen ya esta identificación y citan a Edvvard SARMIENTO, The Original Poems of Fray Luis de León, 1953, p. 79, como el primero en descubrirla. Esta última edición es de Alianza Editorial. Madrid 1986. Oreste Macrí, en la edic. de Edit. Crítica de 1970 recuerda también al personaje de Tibulo y cita a Francisco Rico. Entre los poetas neolatinos del Renacimiento, era frecuente dirigir poemas a algún personaje disfrazado bajo un nombre antiguo, tomado a menudo de los destinatarios de poesías latinas clásicas: In Carinum, In Posthumum, Ad Cherintum... Cf. Francisco Rico, Tradición y contexto en la poesía de Fray Luis, en Academia literaria renacentista. I Fray Luis de León, 246-247. Edic. Univ. de Salamanca 1981. 
signo lingüístico, Dámaso Alonso proclamó su esencial motivación en la expresión poética; mucho más en la poesía en verso y aún más en la lírica ${ }^{51}$. La expresión tiene que asemejarse lo más posible a lo expresado, ceñirse a ello y reproducirlo con los distintos recursos que la lengua tiene. Por eso, Fr. Luis, de entre las palabras que «todos hablan, elige las que convienen, y mira el sonido de ellas, y aun cuenta a veces las letras, y las pesa, y las mide, y las compone, para que no solamente digan con claridad lo que se pretende decir, sino también con armonía y dulzura» (Nombres, 1.3, dedicatoria, 658) ${ }^{52}$. ¿Cómo mantener todo esto en una traducción? Las aliteraciones ${ }^{53} \mathrm{y}$ demás figuras literarias, los acentos y la entonación, el orden de las palabras, los encabalgamientos, la rima y la estrofa... todo este sutil entramado laboriosamente tejido queda fatalmente deshecho. Forma y fondo quedan gravemente averiados. ¿Y los silencios? Saber callar en el momento exacto para que las palabras prolonguen sus vibraciones en el interior del alma y la pueblen de sugerencias dichas sin decirlas. «Los silencios en él tienen un valor poético activo. Ellos amplifican la vibración de onda de belleza en torno a una estrofa» ${ }^{54}$.

¿Qué hay de común en la comunicación establecida entre el lector y Fr. Luis (dígase lo mismo de cualquier otro autor; entre nosotros y Homero, por ejemplo, o entre nosotros y los Salmos) a través de un texto tan distinto del que él compuso y revisó tan cuidadosamente? «Porque las escrituras que por los siglos duran nunca las dicta la boca; del alma salen, adonde por muchos años las compone y examina la verdad y el cuidado» $(J o b 8,10)$. Aun para lectores españoles, está muy lejos de ser satisfactoria la comunicación. Nos separa de él un foso de cuatro siglos, lo que hace que nuestro mundo no sea el suyo. Los estudios rigurosos que sobre él se han hecho muestran la complejidad de su código poético, cultural y lingüístico, así como las muchas zonas que aún quedan por explorar. Ha quedado arrumbada para siempre la imagen de un Fr. Luis de escritura ingenua y espontánea: aquello de «entre las ocupaciones de mis estudios en mi mocedad, y casi en mi niñez, se me cayeron como de entre las manos estas obrecillas, a las cuales me apliqué más por inclinación de mi estrella que por juicio o voluntad» (Poesías, dedicatoria, 431-432, ed. cit.

51. Cf. Poesía española. Ensayo de métodos y límites estilíticos, 31-32 y 599-601. Edit. Gredos. Madrid 1957; Valeriano BÁEz SAN José, La estilística de Dámaso Alonso, 42-56. Publicaciones de la Universidad de Sevilla 1972, 2 a $^{\text {a }}$ edic.

52. Cf. Eugenio de Bustos, Algunas observaciones semiológicas y semánticas en torno a Fr. Luis de León, en AA.VV.: Academia Literaria Renacentista, I. Fray Luis de León, 101-145. Univ. de Salamanca 1981.

53. Cf. Ricardo SENABRE, Aspectos fónicos en la poesía de Fray Luis: voces y ecos, en Academia Literaria Renacentista, 249-269.

54. Dámaso Alonso, Notas sobre Fray Luis de León y la poesía renacentista, en De los siglos oscuros al de oro, 235. Edit. Gredos, 1985, ahora en Obras Completas, II, 773. Edit. Gredos 1973. 
del P. Ángel Custodio Vega) ${ }^{55}$. Eso es una exculpación. Es lo que tenía que decir para no quedar difamado ante los hombres «doctos» y «graves» un religioso, teólogo y escriturista, metido a poeta. ¡Hasta ahí podíamos llegar!

$\mathrm{Y}$, sin embargo, bien venida esta traducción de Fr. Luis, hecha con dedicación e inteligencia. Es un primer paso, pero un paso necesario, para que muchos lectores de lengua francesa conozcan al poeta en quien confluyen, adensadas, todas las voces del Renacimiento, que él depuró, elevándolas a cimas de burilada belleza. «Porque Fr. Luis es eso: Renacimiento español en su riqueza de elementos, en su variedad, en su individualidad; nada más que eso. Y cuando nos pregunten si existe el Renacimiento español, podremos contestar: existe por estas, esas y aquellas razones... O simplemente por esto; porque existe Fr. Luis» ${ }^{56}$.

\section{LA BIBLIOGRAFÍA}

En la bibliografía, sólo se mencionan las obras y artículos escritos en francés o traducidos del español. Habría que añadir la traducción de $L o s$ Nombres de Cristo de Robert Ricard, citada en la p. 10 del prólogo, y las traducciones de La perfecta casada, Nombres de Cristo y de algunas poesías, citadas en las pp. 25 y 27. Faltan también las traducciones que de algunas poesías hicieron Juan María Maury, Paul Rousselot y Eduard Laboulaye, cuya ficha bibliográfica figura en la edic. crítica del P. Custodio Vega. Un error de imprenta ha hecho que Pedro Sáinz Rodríguez, recientemente fallecido y buen conocedor de Fr. Luis, se haya convertido en P. Saint-Rodríguez.

Nada de esto resta méritos al entusiasmo, rigor y lucidez con que Patrick Négrier ha llevado a cabo su tarea de poner al alcance de los lectores de lengua francesa las poesías imperecederas de Fr. Luis. Quienes se acerquen a ellas no quedarán defraudados.

JOSÉ VEGA

Estudio Teológico Agustiniano

Valladolid

55. Cf. Dámaso Alonso, Fr. Luis en la «Dedicatoria» de sus poesías (desdoblamiento y ocultación de la personalidad), Obras Completas, II, 843-868, edic. cit.

56. Dámaso Alonso, Notas sobre Fr. Luis de León y la poesía renacentista, ob. cit., 250; Obras Completas, II, 785. 